\title{
Short-Term/Long-Term Analysis of the Differences in Total Factor Productivity in East and West Asia: A Study of the Main and Interaction Effects
}

\author{
Saeed Jafari ${ }^{1}$ \\ Marziyeh Esfandiari ${ }^{2}$ \\ Mosayeb Pahlavani ${ }^{3}$
}

\author{
saeid904@pgs.usb.ac.ir \\ m.esfandiari@eco.usb.ac.ir \\ pahlavani@eco.usb.ac.ir
}

\begin{abstract}
The present study examines the main and interaction effects of the variables that affect the total factor productivity (TFP) in East and West Asian countries. To this end, this paper provides a short-term and long-term analysis of the factors affecting productivity differences in these countries during the period 1998-2018. According to the results, the main factors that influence the increase in productivity in both the short-term and long-term in East Asia are the share of fossil fuels use, good governance, oil rents, and human capital, respectively; while the most important factors in increasing productivity in West Asia are good governance and trade openness, respectively. Correspondingly, the share of fossil fuels use, human capital, oil rents, foreign direct investment, trade openness, and financial development have been the most important factors in the difference in productivity in East and West Asian countries in both short-term and the long-term. Moreover, good governance has increased the productivity of all factors in West Asian countries (in the short-term), and in East Asian countries (in the long-term). Furthermore, in West Asian countries, in both short-term and long-term, the interaction effect of good governance and oil rents has increased the TFP; also, the interaction effect of human capital and oil rents has reduced the TFP, while the interaction of human capital and foreign direct investment had no effect on the TFP.
\end{abstract}

Keywords: Total Factor Productivity (TFP), East and West Asia, Share of Fossil Fuels, Good Governance, Main and Interaction Effects.

JEL Classification: Q40, Q47, Q49.

1. Ph.D. Student in Economics, University of Sistan and Baluchestan, Zahedan, Iran.

2. Assistant Professor in Economics, University of Sistan and Baluchestan, Zahedan, Iran, (Corresponding Author).

3. Associate Professor in Economics, University of Sistan and Baluchestan, Zahedan, Iran. 


\section{تحليل كوتاهمدت و بلندمدت دلايل تفاوت بهر هورى

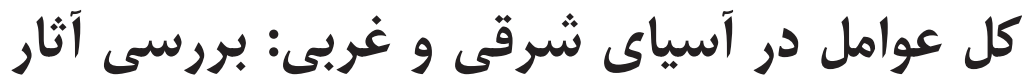

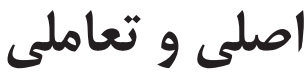

saeid904@pgs.usb.ac.ir

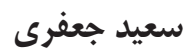

دانشجوى دكترى اقتصاد دانشعاه سيستان و بلوحستان، زاهدان، ايران. m.esfandiari@eco.usb.ac.ir |

مرضيه اسفنديارى

استاديار كروه اقتصاد دانشَاه سيستان و بلوجستان، زاهدان، ايران (نويسنده هسئول). pahlavani@eco.usb.ac.ir |

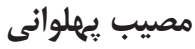

دانشيار كروه اقتصاد دانشكاه سيستان و بلوخستان، زاهدان، ايران.

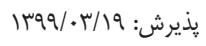

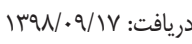

״ جكيده: اين يزوهش با بررسى آثار اصلى و تعاملى هر يك از متغيرهاى اثركذار بر بهرهورى

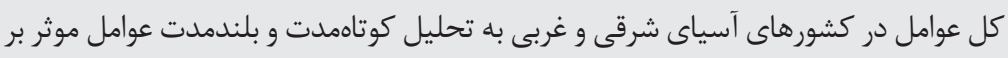

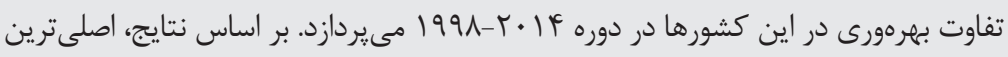

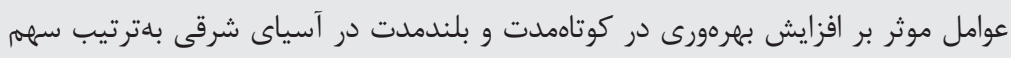

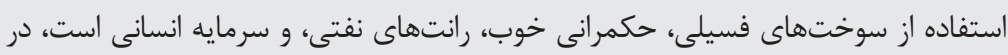

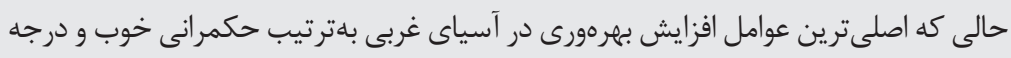

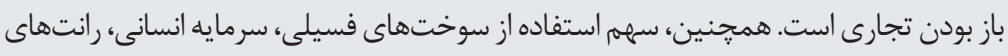

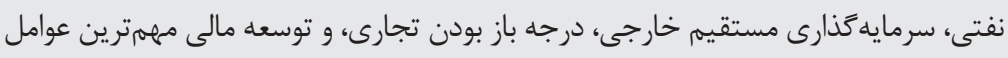

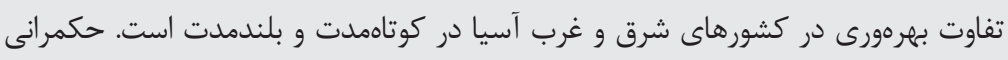

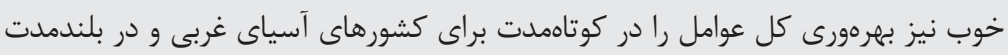

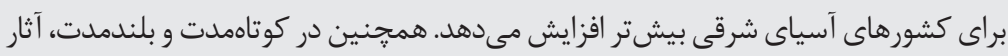

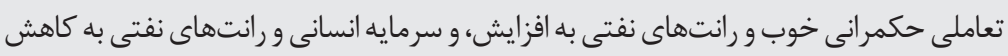

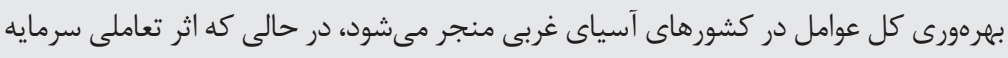

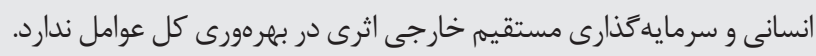

كليدوازهها: بهره ورى كل عوامل توليد، آسياى شرقى و غربى، سهم سوختهاى فسيلى، حكمرانى خوب، آثار اصلى و تعاملى. طبقدبندى Q49, Q47, Q40 :JEL. 


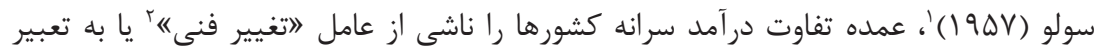

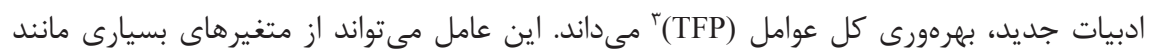

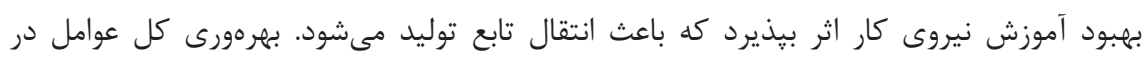

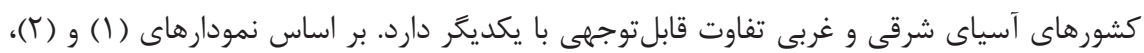

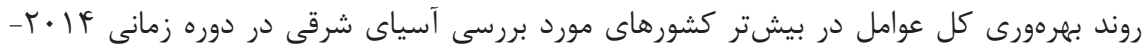
1991 199 صعودى است، در حالى كه اين روند در بيشتر كشورهاى آسياى غربى نزولى يا نوسانى است.

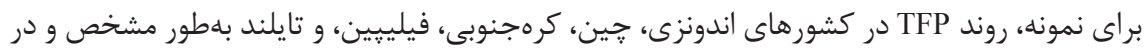

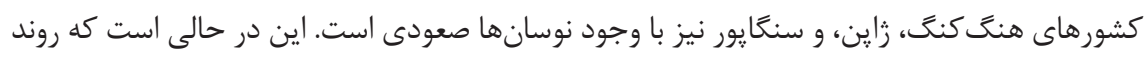

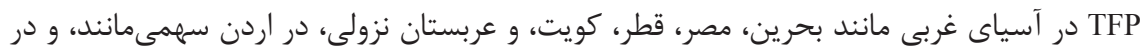

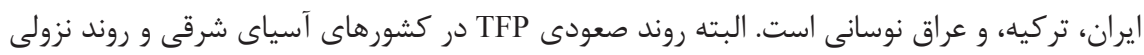

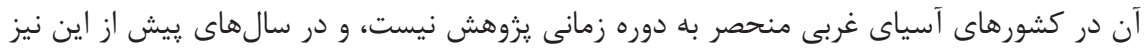

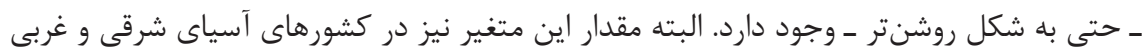

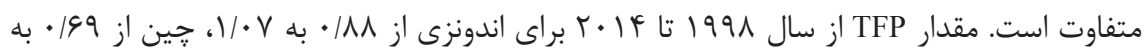

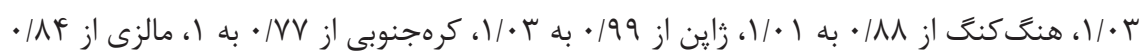

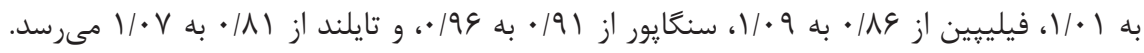
بنابر اين، مقدار TFP در تمام كشورهاى آسياى غربى در انتهاى دوره نسبت به ابتداى آن افزايش دارد.

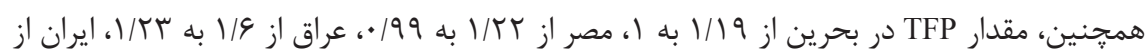

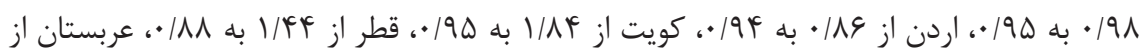

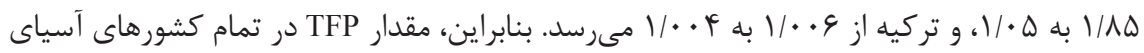

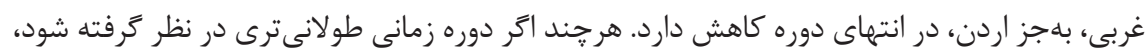

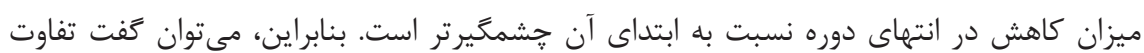
محسوسى بين كشورهاى آسياى شرقى و غربى در روند و مقدار TFP وجود دارد. حال بايد ديد جندي

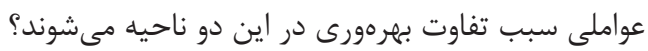

1. Solow

2. Technical Change

3. Total Factor Productivity 

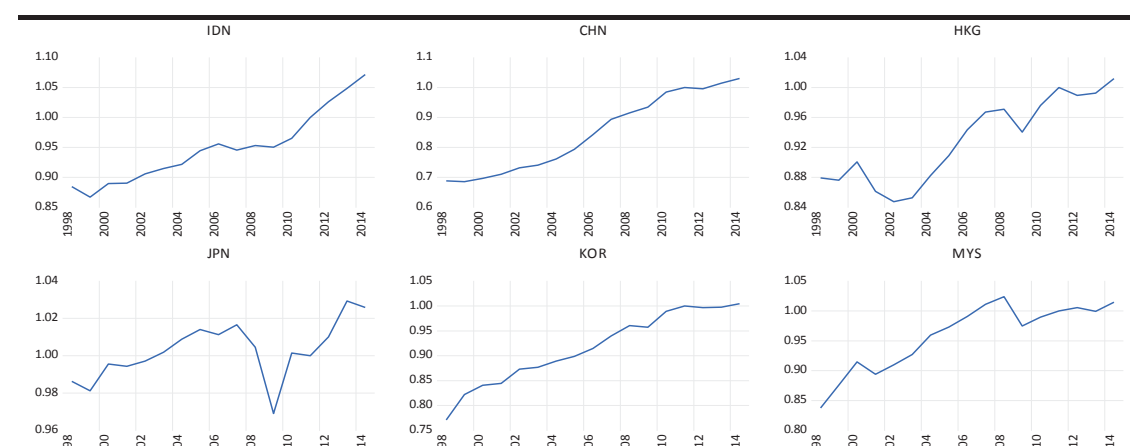

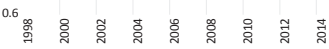
MYs
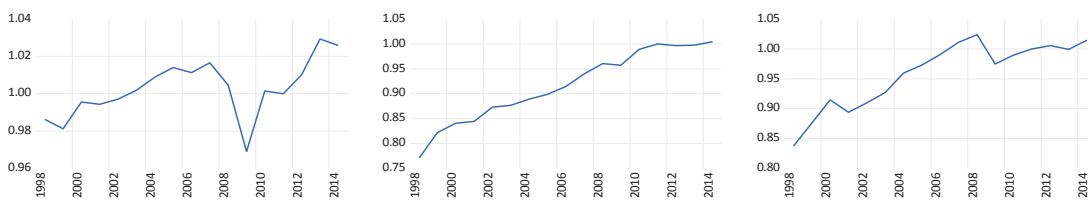
PHL

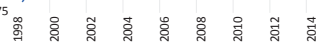

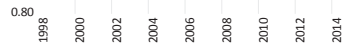
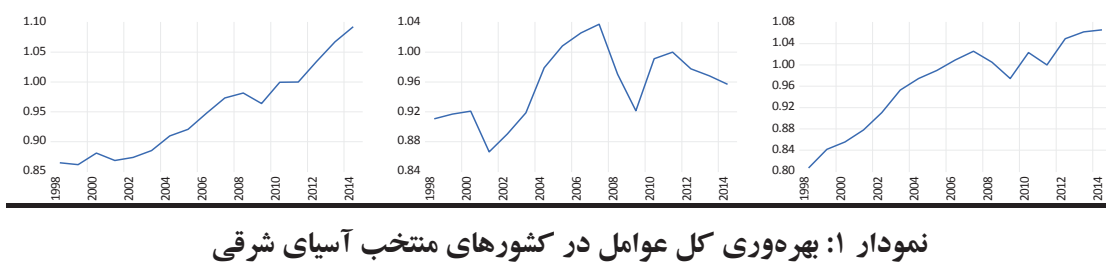

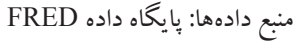
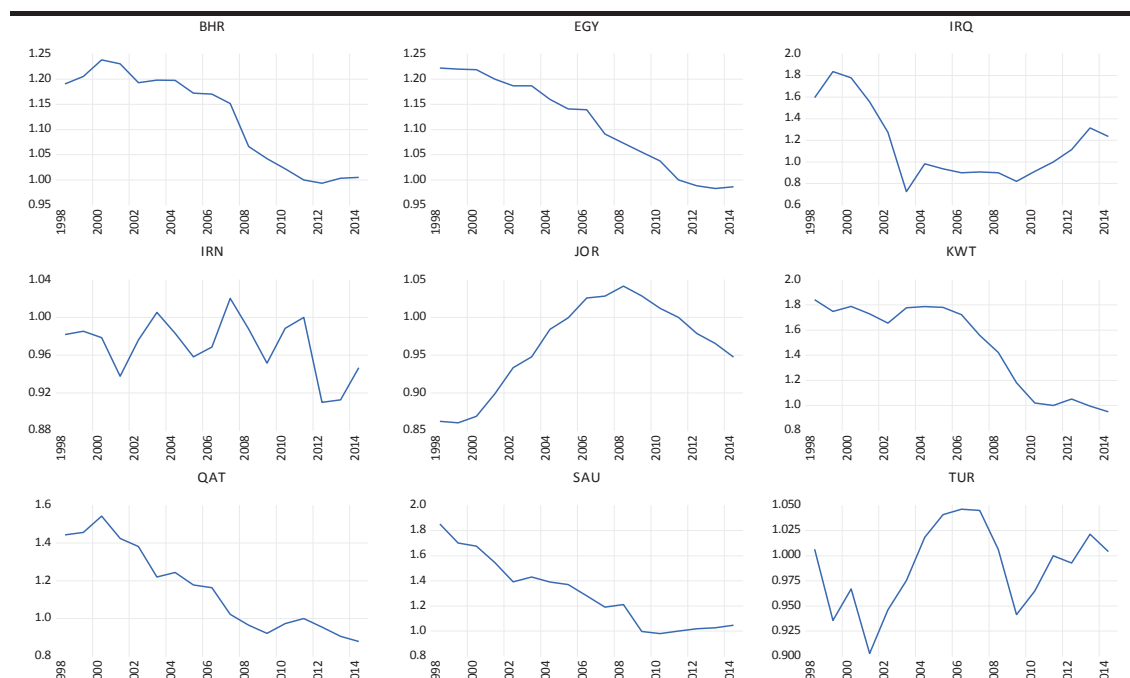

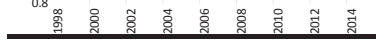

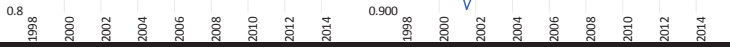


ادبيات گستردهاى ييرامون عوامل اثرگذار بر بهرهورى كل عوامل در قلمروهاى مكانى و زمانى مختلف وجود دارد، و يروهشهاى متنوع، جنبه هاى گوناگون اين موضوع را مورد بررسى قرار مى دهندي. كروهى از يزوهشها، نقش سرمايه انسانى را در بهرهورى كل عوامل مورد توجه قرار مى مدهند كه

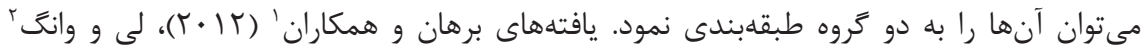

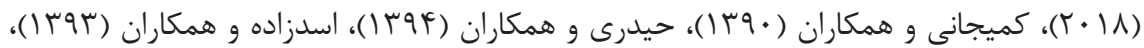

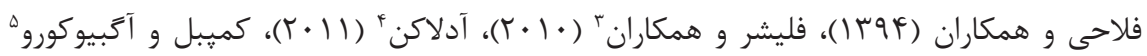

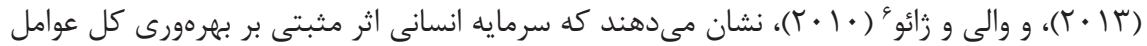

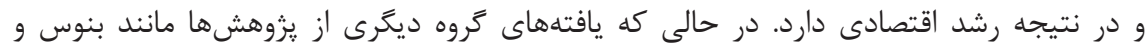

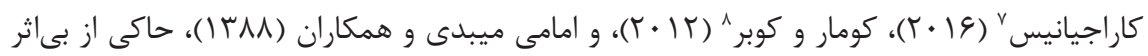
بودن و در يارهاى از موارد، اثر منفى سرمايه انسانى بر بهرهورى و رشد اقتصادى است. با بررسى روند سرمايه انسانى به عنوان يكى از متغيرهاى اثرگذار بر TFP در كشورهاى شرق و غرب آسيا نشاندهنده صعودى بودن روند سرمايه انسانى در اين دو گروه از كشورهاست و مقدئ مقدار

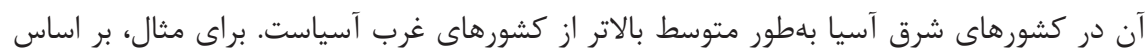

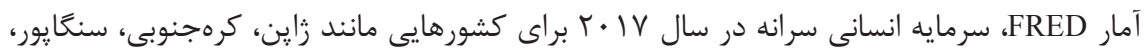

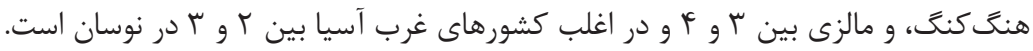

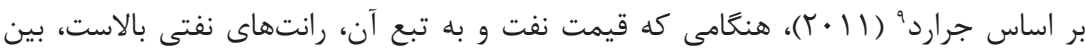

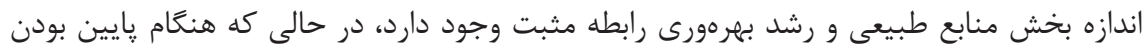
قيمت نفت، بين آنها رابطه منفى برقرار است. به عبارتى ديگر، هنگًامى كه قيمت نفت بالاست،

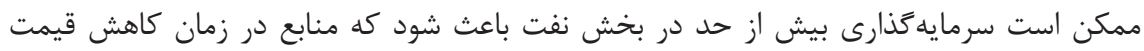

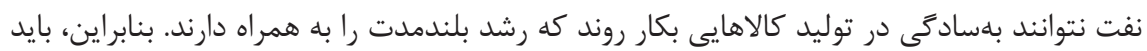
بهجاى وابستكى شديد به منابع طبيعى با كارايى كم مانند نفت، بر توليد كالاها و خدمات بهرهورتر

1. Borhan et al.

2. Li \& Wang

3. Fleisher et al.

4. Adelakun

5. Campbell \& Agbiokoro

6. Whalley \& Zhao

7. Benos \& Karagiannis

8. Kumar \& Kober

9. Gerard 


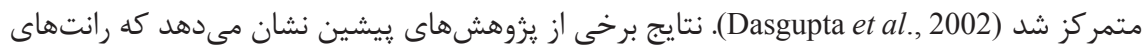

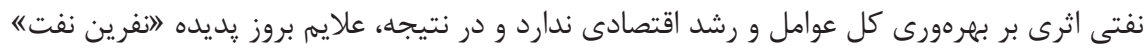

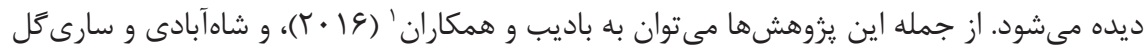
(צوب1) اشاره كرد. هرجند شواهدى از اثر مثبت عوايد نفتى بر بهرهورى نيز در كفايى و باقرزاده

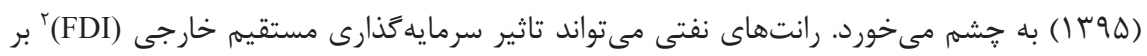
بهرهورى كل عوامل را كاهش دهد (Zidouemba \& Elitcha, 2018). بنابراين، مى توان نقش رانش رانتهاى نفتى (تفاوت بين ارزش توليد نفت خام در قيمت جهانى و هزينه توليد آن)، را در بهرهورى كل عل عوامل دوران

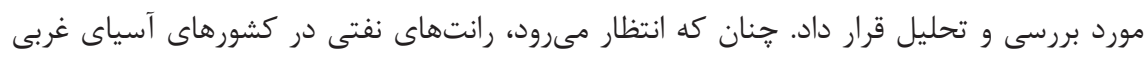
بيشتر از كشورهاى شرق آسياست.

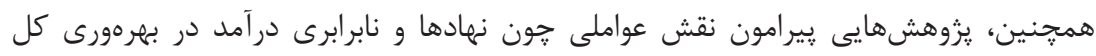

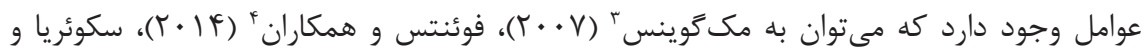

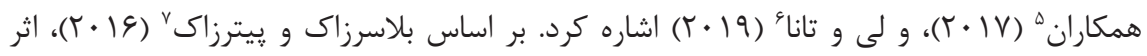

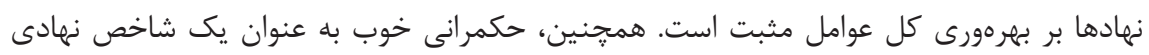

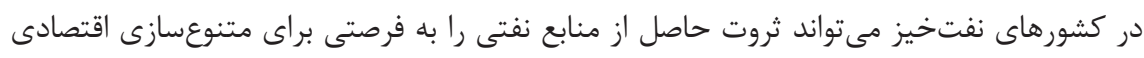

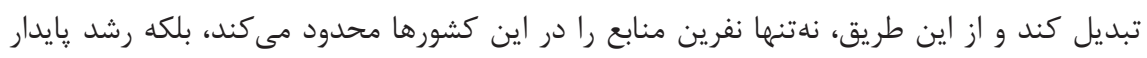

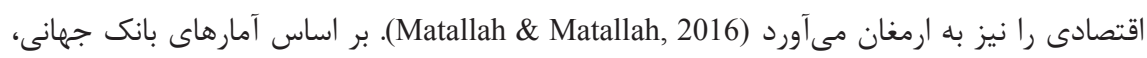
شاخصهاى حكمرانى خوب در كشورهاى شرق آسيا بهطور متوسط مطلوبتر از كشورهاى غرب

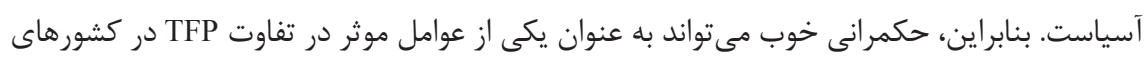

$$
\text { شرق و غرب آسيا مورد بررسى قرار گيرد. }
$$

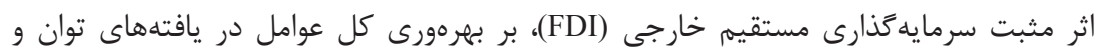

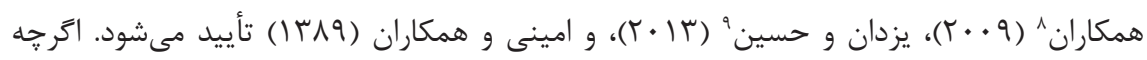

1. Badeeb et al.

2. Foreign Direct Investment

3. McGuinness

4. Fuentes et al.

5. Sequeira et al.

6. Li \& Tanna

7. Balcerzak \& Pietrzak

ITV

8. Tuan et al.

9. Yazdan \& Hossein 
بر اساس لى و تانا (9 ( †)، اثر مستقيم سرمايهَّارى مستقيم خارجى در كشورهاى درحالتوسعه بهتنهايى ناجيز است، اما با در نظرگرفتن اثر تعاملى FDI با سرمايه انسانى و شاخصهاى نهادى،

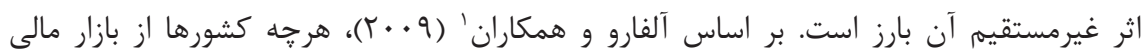
توسعهيافتهترى برخوردار باشند، منفعت بيشترى از سرمايه گذارى مستقيم خارجى بهدست مى آورند.

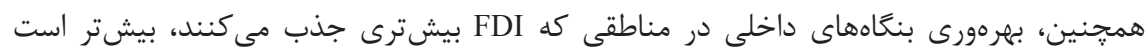

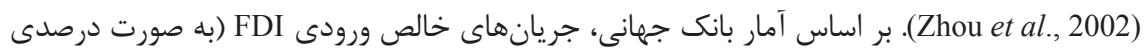
از توليد ناخالص داخلى)، در كشورهاى شرق آسيا بهطور متوسط بيشتر از كشورهاى غرب آنآ آسياست.

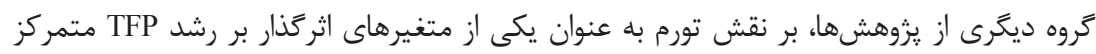

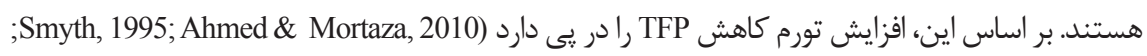

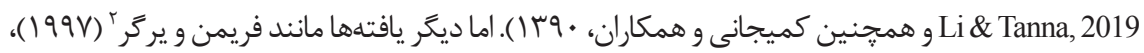

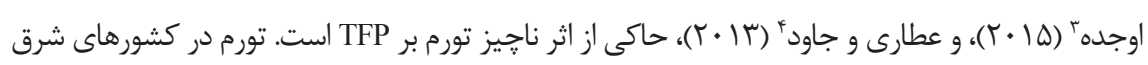
آسيا بهطور برجستهاى كمتر از غرب آسياست، و اين ديخر وجه تمايز كشورهاى غرب باش آشرق آسياست.

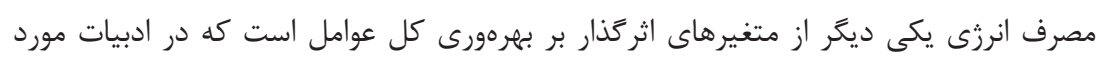

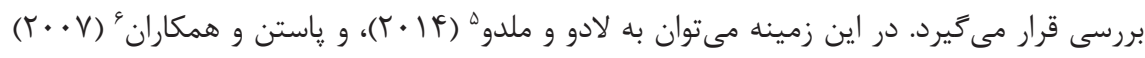

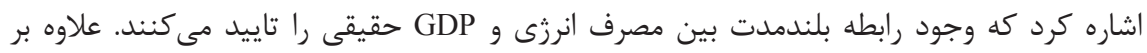

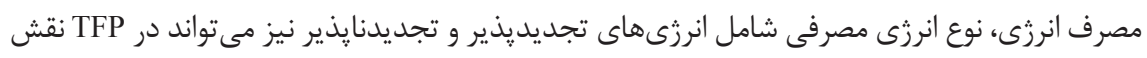

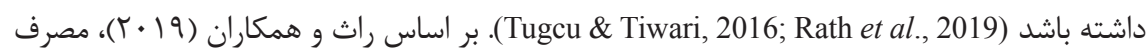
سوختهاى فسيلى TFP را كاهش مى دهد، در حالى كه مصرف انرزى هاى تجديديذير سبب افزايش آن

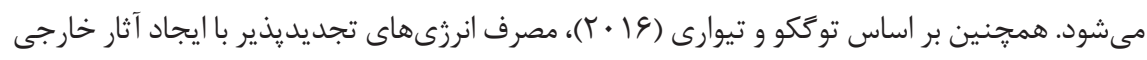

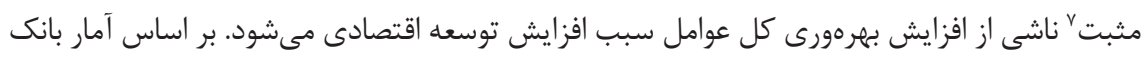
جهانى، عمده مصرف انرزى در كشورهاى شرق و غرب آسيا مربوط به سوختهات آنى فسيلى است، اما

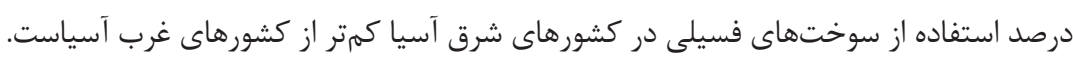

\section{Alfaro et al.}

2. Freeman \& Yerger

3. Ojede

4. Attari \& Javed

5. Ladu \& Meleddu

6. Pasten et al.

7. Positive Externalities 
درجه باز بودن تجارى و توسعه مالى از ديگر متغيرهاى اثركذار بر TFP است كه در ادبيات مورد

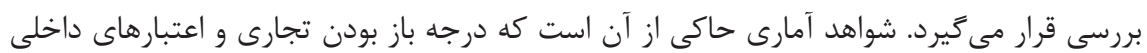

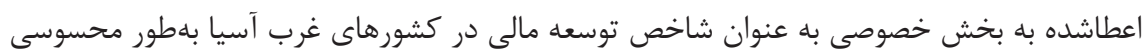

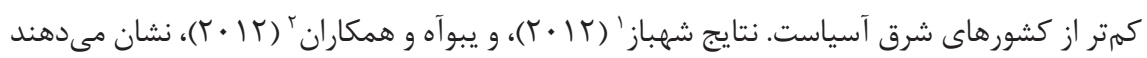

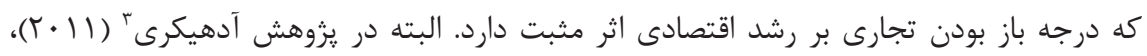
درجه باز بودن تجارى رشد اقتصادى را در بنگكلادش كاهش مى دهد. همجنين، توسعه مالى مى توتواند

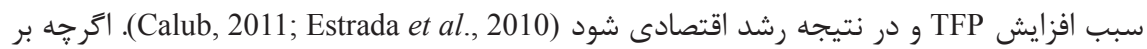
اساس انوار و سان (11 (Y)، توسعه مالى اثر معنادارى بر رشد اقتصادى ندارد.

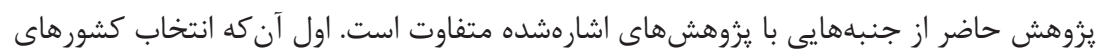
شرق و غرب آسيا با توجه به تفاوت بهرهورى كل عوامل در اين مناطق و با هدف بروسئ بروسى علت آن،

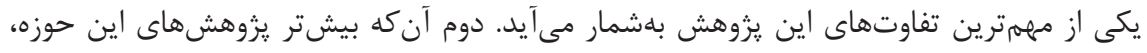

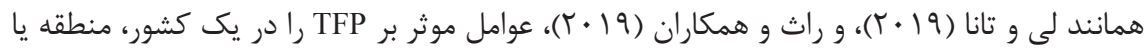

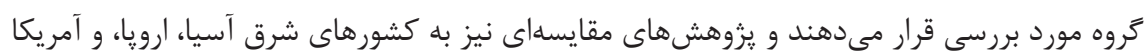

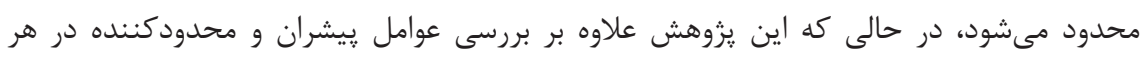

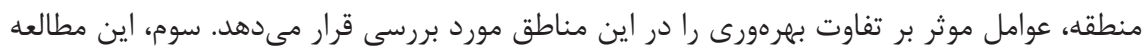

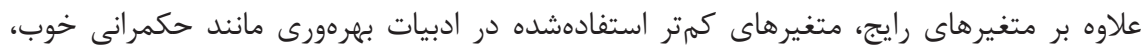

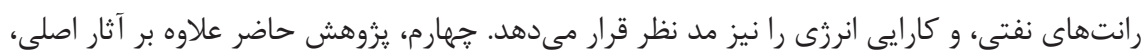

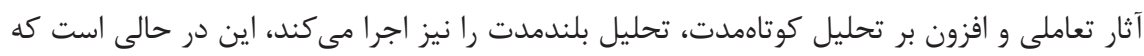

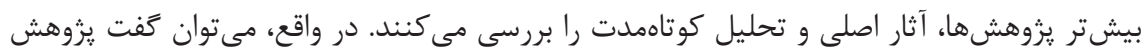
حاضر تجميع ادبيات در اين حوزه است. هدف يزوهش اين است كه با تشكيل دو گروه مجزا از كشورهاى منتخب آسياى شرقى و غربى، ميزان اثرَذارى هر يك از عواملى كه مسبب تفاوت بهرهورى در اين دو كروه از كشورها هستند،

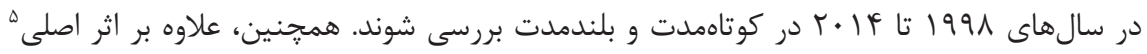

1. Shahbaz

2. Yeboah et al.

3. Adhikary 
متغيرها، به بررسى آثار تعاملى' متغيرهايى مانند سرمايه انسانى، رانتهاى نفتى، و حكمرانى خوب يرداخته مىشود. براى اين منظور در بخشهاى بعدى، يس إز بيان مبانى نظرى به معرفى دادهها و

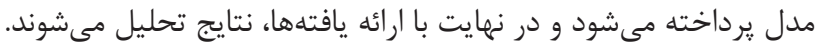

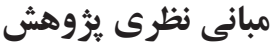

سولو (צه9 ()، در ابتدا مدل رشد خود را بر اساس تابع توليد شكل اين تابع توليد را به صورت كاب داكلاس مدل رشد خود را مبتنى بر آن نمايش مى دهد. در اين مدل، Y مقدار كل محصول، $K$ مل كل موجودى سرمايه، و L مقدار كل نيروى كار است. همجنين، $\alpha$ سهم نسبى سرمايه از كل محصول و م-1 سهمم نسبى نيروى كار از كل محصول است. اما نتايج مفهومى مدل و نتايج برآورد تجربى آن قادر به توضيح

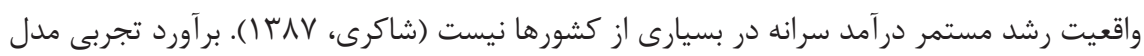

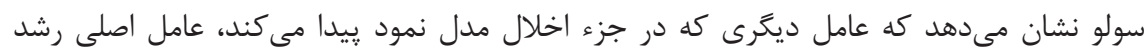
در آمد سرانه كشورهاست. سولو (9DV (1)، اين عامل را تحت عنوان A التغيير فنى" ياد مى كند و تابع توليد جديد خود را با شمول اين عامل به صورت

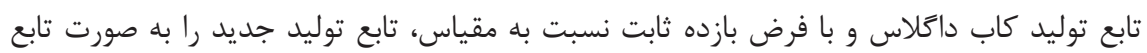
(1) (1) (1ائه ميى كند: (1)

$Y=A K^{\alpha} L^{1-\alpha}$

اين عامل تحت عنوان شاخص بىاطلاعى ما؟، پِماند سولوّ، رشد بهرهورى جندنهادهاى"، و

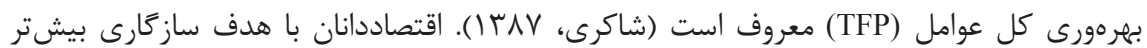

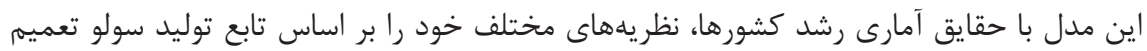
مى دهند. برخى تاثير اين عامل را در افزايش اثربخشى نيروى كار مىدانند و بر اساس آن مدل ييشرفته سولو را به صورت

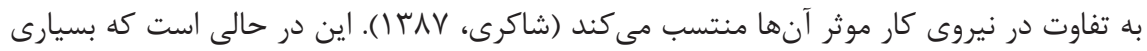

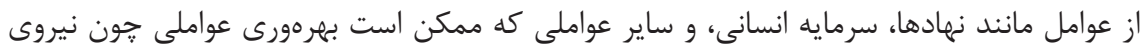

1. Interaction Effect

2. The Measure of Our Ignorance

3. Solow Residual

4. Multifactor Productivity 
كار، سرمايه، و انرزى را افزايش دهند، در اين مدل ناديده گرفته مىشود. منكيو و همكاران' (1994)،

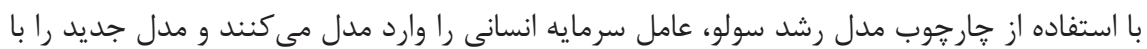
شمول سرمايه انسانى به صورت برآورد A از معادله بالا به اين نتيجه مىرسند كه اين عامل، تمام عواملى كه تفاوت را در محصول سرانه

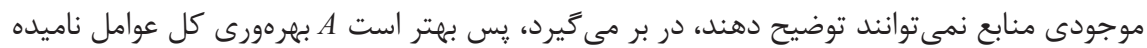

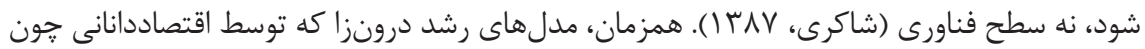

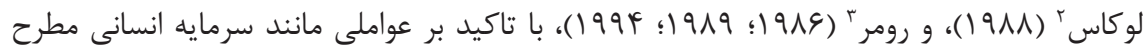

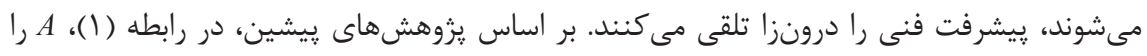

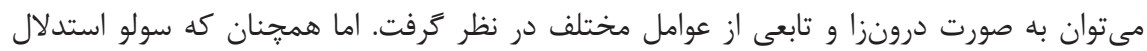
مى كند، عمده تفاوت رشد اقتصادى كشورها ناشى از رشد اين عامل است، نه رشد عوامل اصلى توليد.

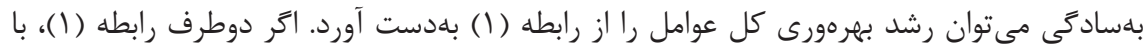

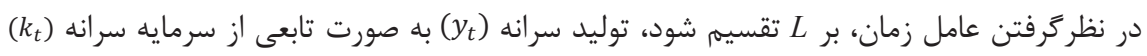
$y_{t}=A_{t}\left(\frac{K}{L}\right)^{\alpha}=A_{t}\left(k_{t}\right)^{\alpha}$ بdدست مى آيد: كه در آن

$\log \left(y_{t}\right)=\log \left(A_{t}\right)+\alpha \log \left(k_{t}\right)$

در نهايت مى توان با ديفرانسيل كيرى از رابطه بالاو يك جابهجايى ساده، رشد بهرهورى كل عوامل

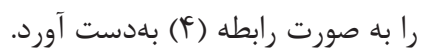

$\dot{y}_{t}=\dot{A}_{t}+\alpha \dot{k}_{t}$

$\dot{A}_{t}=\dot{y}_{t}-\alpha \dot{k}_{t}$

بخش اول رابطه (f) نشان مى دهد كه رشد اقتصادى از مجموع رشد بهرهورى كل عوامل و رشد

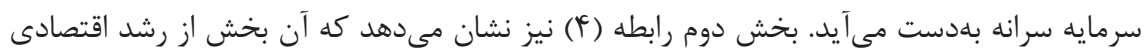

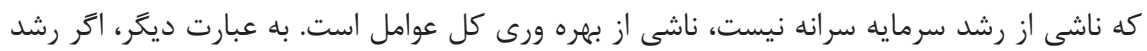

1. Mankiw et al.

|fI

2. Lucas

3. Romer 
سرمايه سرانه از رشد اقتصادى كم شود، رشد بهرهورى كل عوامل بهدست مى آيد. اما همجنان كه بيان

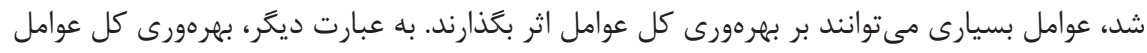
را مىتوان به صورت تابعى از عوامل مختلف در نظر گرفت (Zhou et al., 2002): $A_{t}=T F P_{t}=F\left(x_{i}\right)=F\left(x_{1}, x_{2}, \ldots, x_{n}\right)$

بنابراين TFP تابعى از تمام عواملى است كه بهنوعى سبب افزايش يا كاهش بهرهورى كل عوامل

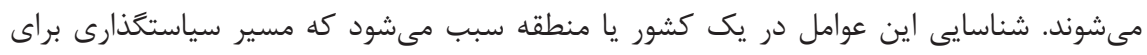

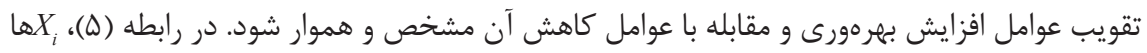
تمام عواملى هستند كه مى توانند در تغيير TFP نقش داشته باشند. اين عوامل مىتواند شامل سرمايه

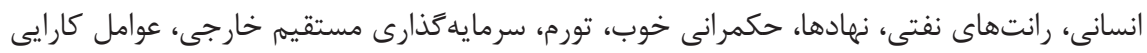

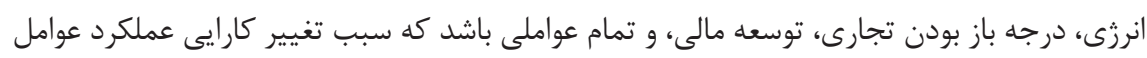

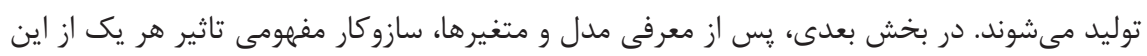

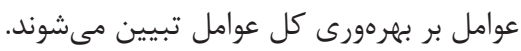

\section{معرفى دادهها و تصريح مدل}

بر اساس آنجه بيان شد، TFP مىتواند تابعى از عوامل مختلف باشد. با توجه به اينكه ساختار

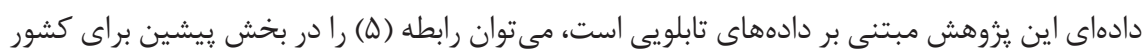
i در زمان t به صورت رابطه (9) نوشت:

$\operatorname{TFP}_{i t}=F\left(x_{i t}\right)$

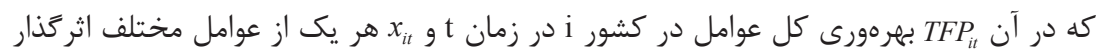
بر TFP در كشور i در زمان t است. در اين يزوهش بر اساس ادبيات بهرهورى كل عوامل و ساختار

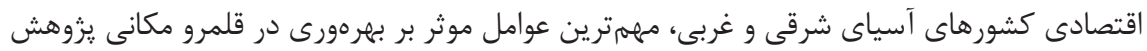

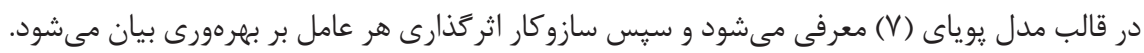
$T F P_{i t}=\alpha_{0} T F P_{i t-1}+\beta_{j} x_{i t}+\mu_{i}+\varepsilon_{i t}$

كه در آن X بردارى از متغيرهاى سرمايه انسانى، رانتهاى نفتى، شاخص حكمرانى خوب، درصد استفاده

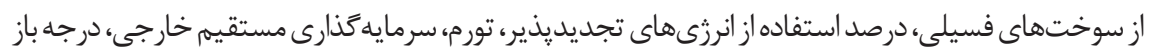

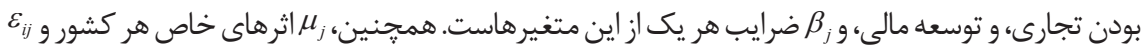




$$
\begin{aligned}
& \text { جزء اخلال تصادفى مدل است. همجنين، تمام متغيرهاى مدل به صورت للخاريتمى تصريح مىشوند. به علاوه، }
\end{aligned}
$$

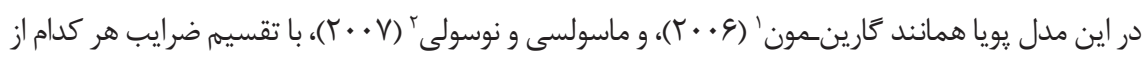

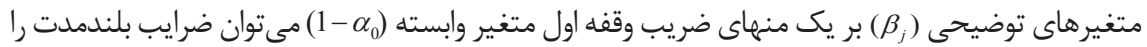

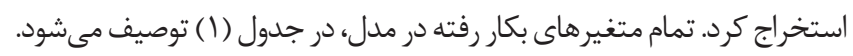

\section{جدول ا: معرفى و توصيف متغيرها}

\begin{tabular}{|c|c|c|c|c|}
\hline منبع & انتظارى & توضيح & توصيف & متغير \\
\hline 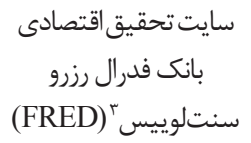 & متغيروابسته & 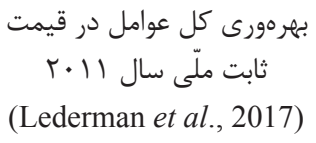 & بهرهورى كل عوامل توليد & TFP \\
\hline $\begin{array}{c}\text { سايت تحقيق اقتصادى فدرال رزرو } \\
\text { سنتلوييس } \\
\text { (FRED) }\end{array}$ & مثبت (+) & 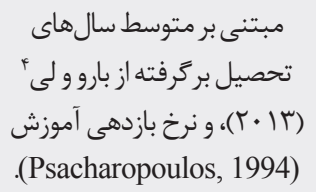 & 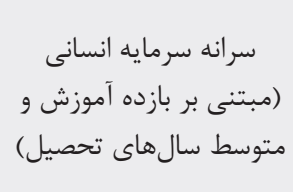 & سرمايه \\
\hline بانك جهانىه & مثبت (+) يا & تفاوت بين توليد نفت خام & $\begin{array}{c}\text { درانتهاى نفتى به صورت از توليد ناخالص } \\
\text { داخلى (GDP) }\end{array}$ & رنفتى \\
\hline بانك جهانى v & مثبت (+) & 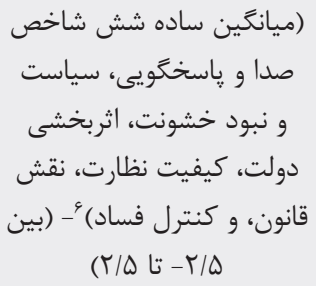 & شاخص حكمرانى & حوب حمرائ \\
\hline
\end{tabular}

\section{Garín-Mun}

2. Musolesi \& Nosvelli

3. https://fred.stlouisfed.org/

4. Barro \& Lee

5. https://databank.worldbank.org/source/world-development-indicators

6. Voice and Accountability-Political and Absence of Violent-Government EffectivenessRegulatory Quality-Rule of Law-Control of Corruption

7. World Bank World Wise Governance Indicators 
ادامه جدول ا: معرفى و توصيف متغيرها

\begin{tabular}{|c|c|c|c|c|}
\hline منبع & عانامت انظارى & توضيح & توصيف & متغير \\
\hline بانك جهانى & مثبت (+) يا & 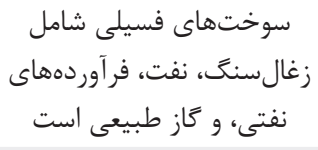 & سوختهاى فهيلم استفاده از از كل & سوختهاى \\
\hline بانك جهانى & مثبت (+) & 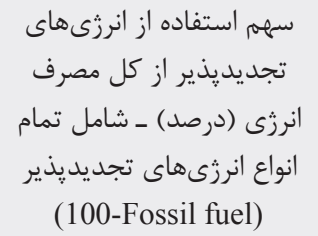 & سجدم استفاده از انرزىهاى & تجديديذهير \\
\hline بانك جهانى & مثبت (+) يا & 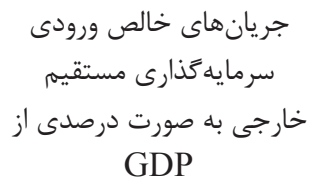 & سرمايه گذارى مستقيم & FDI \\
\hline بانك جهانى & منفى (-) & قرصد تغيير سالانه شاخص كالاها و خدمات & تورم & 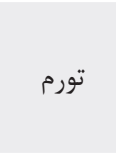 \\
\hline بانك جهانى & مثبت (+) & صجموع صادرات و واردات به درصدى از GDP & درجه باز بودن تجارى & باز بودن تجارى \\
\hline بانك جهانى & مثبت (+) يا & 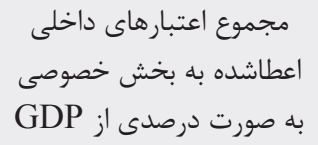 & توسعه مالى & توسعه \\
\hline
\end{tabular}

يس از معرفى مدل و توصيف متغيرهاى آن، لازم است سازوكار اثركذارى هر كدام از آنها بر TFP

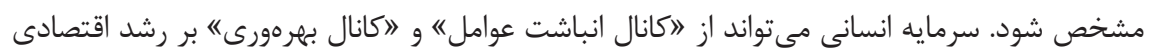

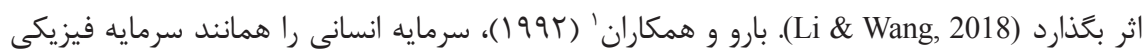
به عنوان يكى از عوامل توليد در نظر مى 
به عنوان يك عامل توليد نتيجه مىشود. در مقابل، نلسون و فليس' (999 (19)، نشان مىدهند كه نحوه اثرگذارى سرمايه انسانى متفاوت از سرمايه فيزيكى است، و در نتيجه در نظركرفتن سرمايه انسانى به

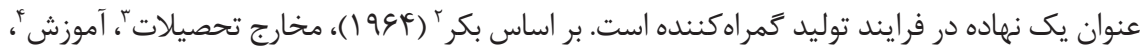
و مراقبتهاى يزشكى ه انواع مختلف سرمايهَذارى هستند كه البته مالى و فيزيكى نيستند؛ جرا كه هيج كس رانمىتوان از دانش، مهارتها، سلامتى، و ارزش هايش جدا كرد. بنابراين، نكاه يكسان به سرمايه

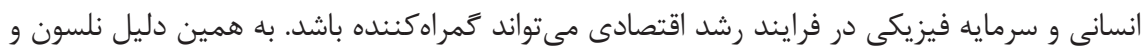

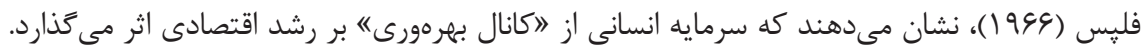
اين بدان معناست كه كشورهايى كه انباشت سرمايه انسانى بيشترى دارند، مىتوانند نوآورى بيشترى فيش

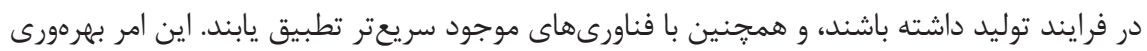
كل عوامل و خلق ارزشافزوده را افزايش مىدهد

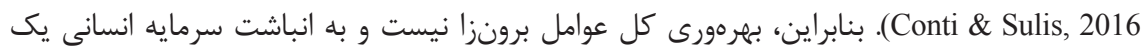

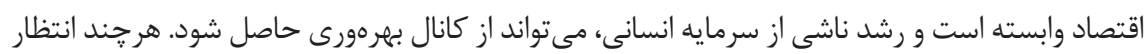
مىرود كشورهايى كه از منابع طبيعى فراوانى برخوردارند، رشد اقتصادى بالايى نيز داشته باشند، اما

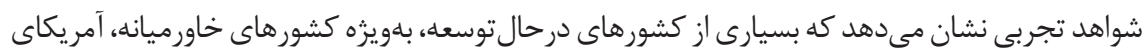

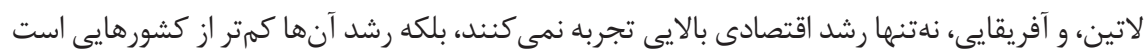

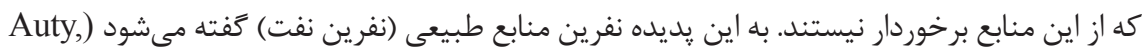

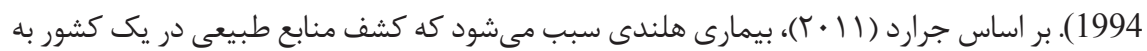

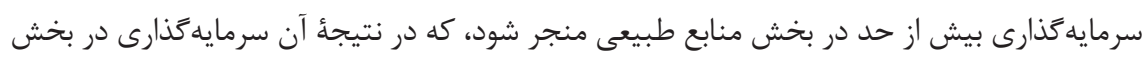

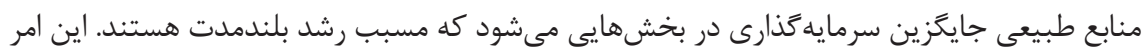

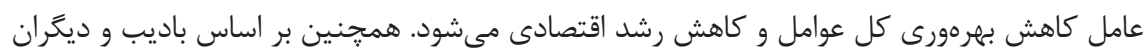

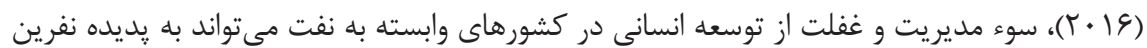
نفت منجر شود. همجنين، دسترسى آسان به رانتهاى نفتى سبب مىشود كه دولت به توسعه سرمايه

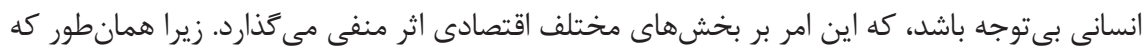
نلسون و فليس (999 (19) تاكيد مى كنند، غفلت از سرمايه انسانى بهرهورى كل عوامل را كاهش ميى مدهد.

1. Nelson \& Phelps

2. Becker

3. Expenditures on Education

4. Training

5. Medical Cares 
از طرفى بر اساس زيدوامبا و اليتجا (1) • (Y)، سرمايهَذارانى كه به سمت كشورهاى غنى از منابع نفتى مىروند، بيشتر به فكر استفاده از رانتهاى نفتى هستند تا افزايش بهرهورى. به علاوه، افزايش رانتهاى

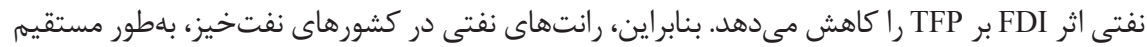
يا از طريق تاثير بر ساير عوامل، TFP را تحت تاثير قرار مىدهد. از اينرو، با توجه به اينكه بيشتر

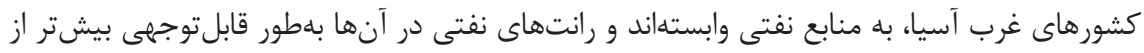

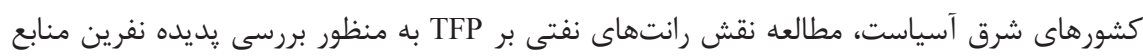
ضرورى به نظر مىرسد.

حكمرانى خوب به عنوان يكى از مهمترين شاخصهاى نهادى مىتواند بر بهرهورى كل عوامل

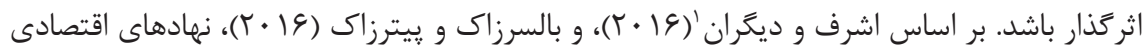

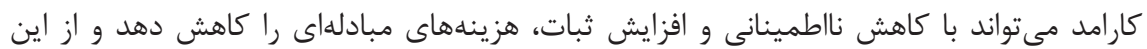
طريق، باعث تخصيص كارامد منابع و گسترش دانش و ايدهاى جديد شود، كه اين امر افزايش

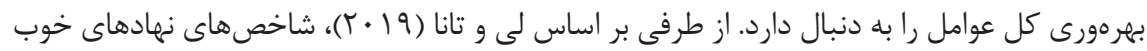

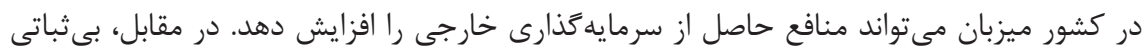

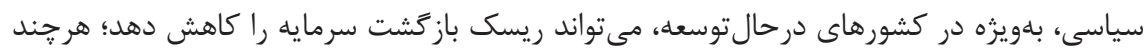

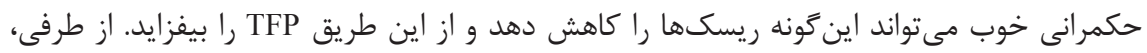

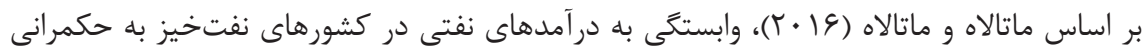
ضعيف منجر مىشود، هرا كه وابستخى زياد به منابع نفتى ساخت نهادهاى اقتصادى با كيفيت بالا را دشوار مى كند و باعث تشويق فعاليتهاى رانتجويانه و در نتيجه كاهش رشد اقتصادى مى شود.

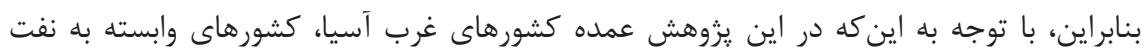

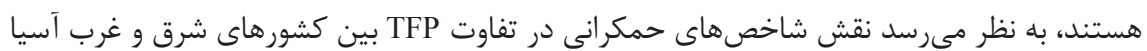
قابلتوجه باشد.

مصرف انرزى از كانال فناورى، كارايى فرايند توليد و TFP را افزايش مىدهد ( Moghaddasi \&

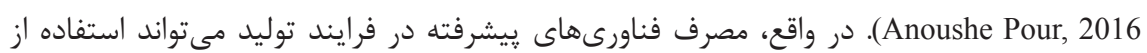

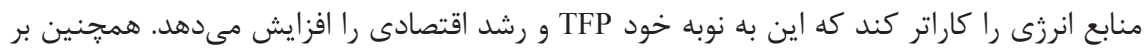

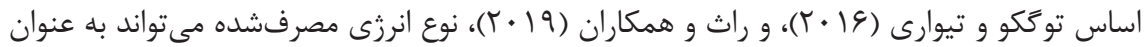

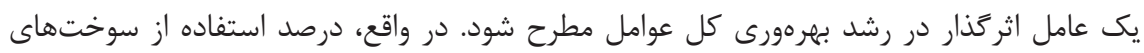


فسيلى و انرزىهاى تجديديذير مىتواند TFP را تحت تاثير قرار دهد. همجنين بر اساس حيدر و

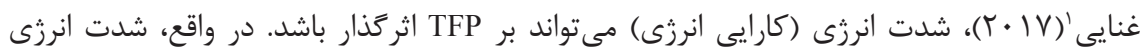
ֶايين يا به عبارت ديخر، كارايى انرزى بالا به معنى استفاده از فناورى يِيشرفتهتر در فرايند توليد است

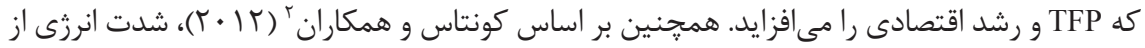
طريق فناورىهاى كارايى بخش انرزى مىتواند بر TFP اثركذار باشد. همجنين، انتظار مىرود استفاده از سوختهاى فسيلى كه تجديدنايذير هستند، سبب كاهش TFP شود و استفاده از سوختهاى تجديديذير TFP را افزايش دهد. هرجند استفاده از سوختهاى فسيلى با فناورىهاى كارايىبخش

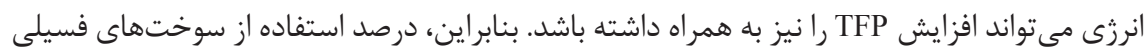

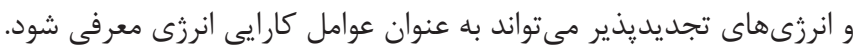
سرمايهَذارى مستقيم خارجى نيز از يكسو با افزايش تشكيل سرمايه ناخالص، نرخ تشكيل نشيل سرمايه را افزايش مىدهد، و از سوى ديخر با بهبود فضاى رقابتى، اثرهاى خارجى مثبت فناورى و

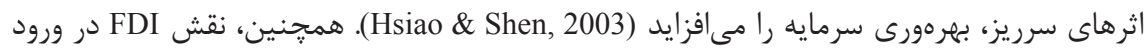
و انتقال فناورىهاى پِيشرفته و شيوههاى مدرن مديريتى - بهويزه در كشورهاى درحالتوسعه ـ انكارنايذير است (Zho et al., 2002; Li \& Tanna, 2019). همجنين تورم در طرف تقاضا، با كاهش در آمد حقيقى افراد، قدرت خريد آنها را كاهش مى دهد

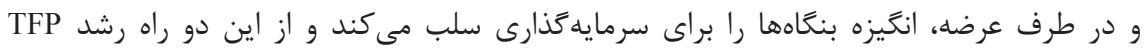
را كاهش مى دهد (Li \& Tanna, 2019). در واقع، تورم با تاثير بر قيمتهاى نسبى و تصميمهاى سرمايهَذاران، هزينههايى بر توليد تحميل مى كند (Mahadevan \& Asafu-Adjaye, 2005). توسعه مالى سبب مىشود كه فرصتهاى بيشترى براى متنوعسازى و ريسك يذيرى بهوجود آيد و

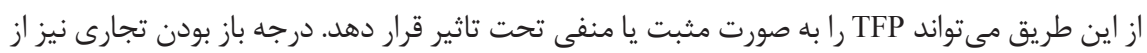

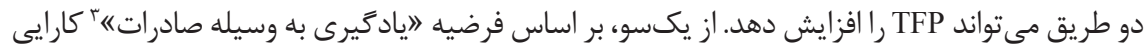
يك بنگًاه با ورود به بازارهاى صادراتى افزايش ميى يابد (De Loecker, 2013)، و از سوى ديكر گسترش مبادلههاى تجارى مىتواند رشد TFP را به همراه داشته باشد (Li \& Tanna, 2019).

1. Haider \& Ganaie 


\section{بر آورد مدل و ارائه يافتهها}

در اين بخش، با توجه به مدل ارائهشده در بخش يُشين، به برآورد مدل و سيس ارائه يافتهها

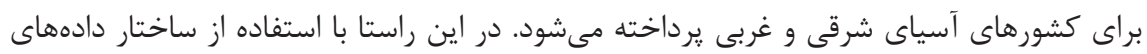
تابلويى، دو مدل مجزا، يكى براى كشورهاى آسياى شرقى و ديغرى براى كشورهاى آسياى غربى غريى برآورد مىشود. كشورهاى شرق آسيا شامل زاين، كرهجنوبى، اندونزى، جين، هنَ كنَ، مالزى،

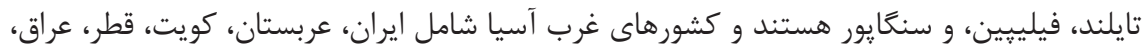
بحرين، اردن، مصر، و تركيه. كشورهاى مصر و تركيه به علت نزديكى بسيار زياد به كشورهاى آسيايى و دارا بودن يك ناحيه آسيايى به عنوان كشورهاى ناحيه غرب آسيا آورده مىشوند. همانطور كه در در

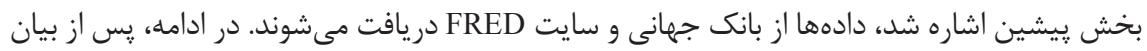

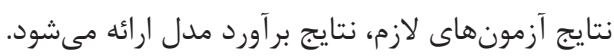

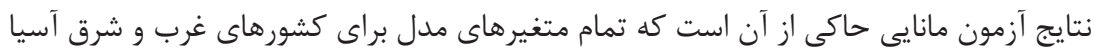

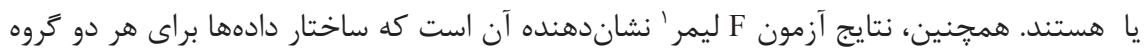
از كشورهاى آسياى شرقى و غربى يانل است. از طرفى در اين يزوهش، به منظور كنترل درونزايى

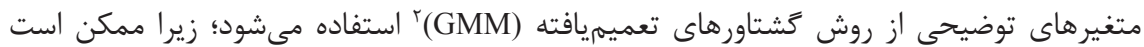
متغيرهاى سرمايه انسانى، سرمايه گذارى مستقيم خارجى، تورم، مصرف انرزى، رانتهاى نفتى، درجيه باز بودن تجارى، و توسعه مالى علاوه بر اثرگذارى بر بهرهورى كل عوامل، تحت تاثير آن نيز قرار گيرند.

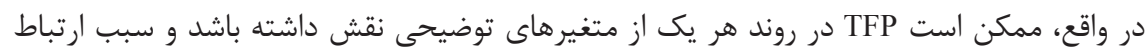

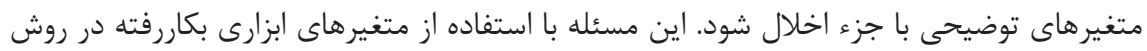

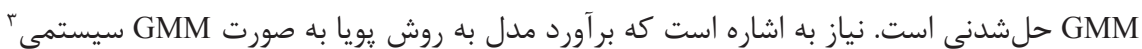

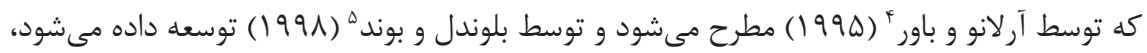

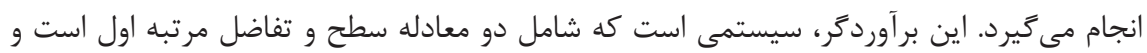
جايخزينى براى برآوردگر تفاضل مرتبه اول استاندارد است. به منظور بررسى اعتبار متغيرهاى ابزارى

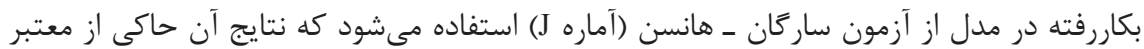

1. F-Limer Test

2. Generalized Method of Moments

3. System-GMM

4. Arellano \& Bover

5. Blundell \& Bond 


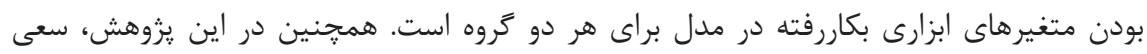

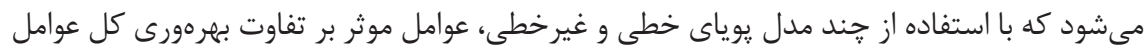

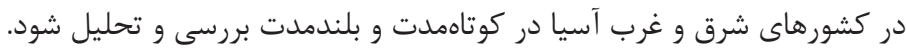

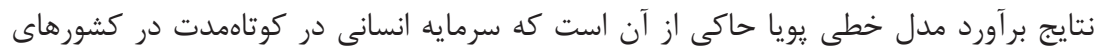

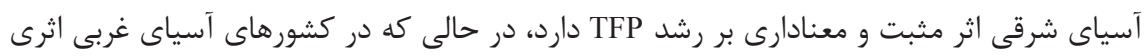

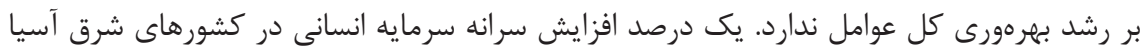

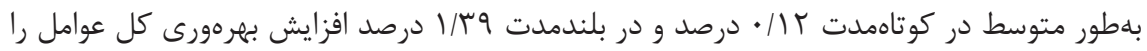

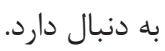

همجنين بر اساس نتايج يزوهش، استفاده بيشتر از سوختهاى فسيلى بهرهورى كل عوامل

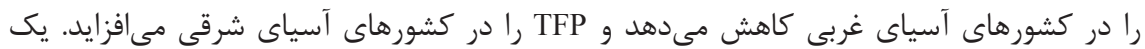

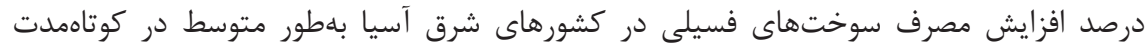

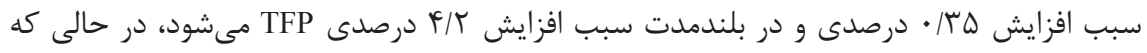

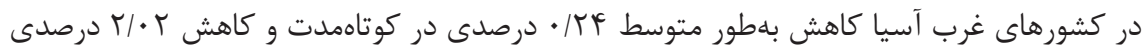

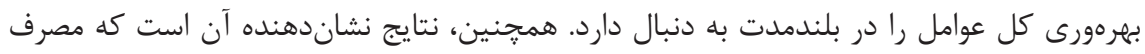

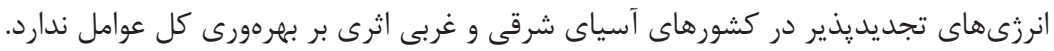

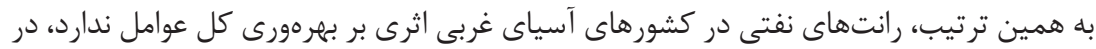

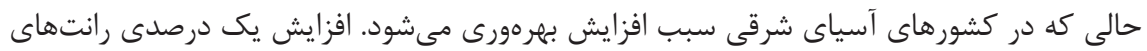

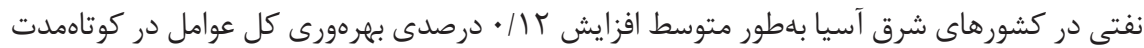

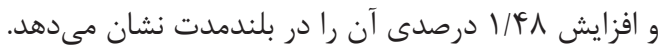

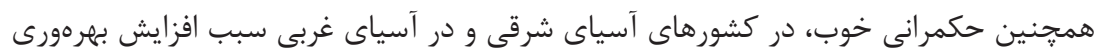

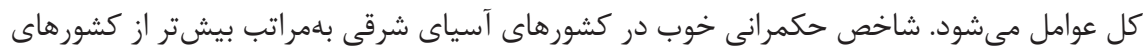

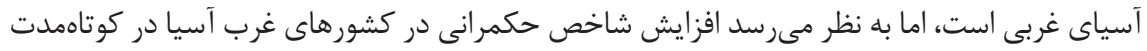

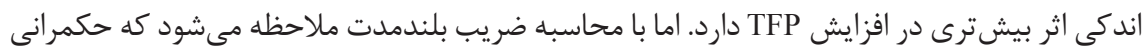
خوب اثر بيشترى در افزايش بهرهورى كل عوامل در كشورهاى آسياى شرقى نسبت به بـ كشورهاى آسياى غربى دارد.

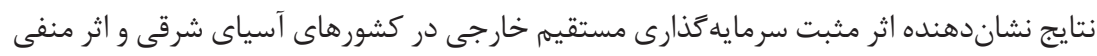

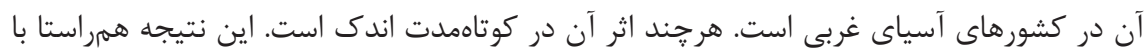


نتايج لى و تانا (9 ( † )، در مورد برخى از كشورهاى غرب آفريقاست. اما در بلندمدت، تفاوت بهرهورى

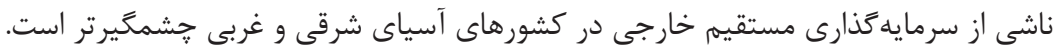
علاوه بر اين، نتايج حاكى از اثر مثبت باز بودن تجارى بر TFP در كشورهاى آسياى غربى و بى اثى بودن آن بر بهرهورى در كشورهاى آسياى شرقى در كوتاهمدت است. همجنين، تورم همجنان كه انتظار مىرود، در هر دو كشورهاى آسياى شرقى و آسياى غربى با كاهش در آمدهاى حقيقى و سلب

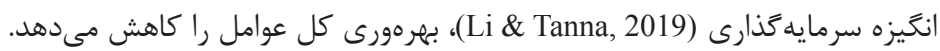
در نهايت، توسعه مالى به صورت اعتبارهاى اعطاشده به بخش خصوصى در كشورهاى آسياى غربى سبب كاهش بهرهورى كل عوامل مىشود، در حالى كه در كشورهاى شرق آسيا اثرى بر بهرهورى كل عوامل ندارد. ضرايب بلندمدت در جدول (ז)، با تقسيم كردن ضرايب كوتاهمدت به يك منهاى ضريب متغير :كرد وابسته با يك وقفه محاسبه مىشود. جند نكته در مورد ضرايب بلندمدت بيانشدنى است؛ اول آن كه ضريب متغير وابسته با يك وقفه در كشورهاى آسياى شرقى و غربى كمتر از يك است كن كه اين مسئله سبب مىشود علامت ضرايب بلندمدت همجههت با ضرايب كوتاهمدت باشد. دوم آن كه ضر ايب ونبي بلندمدت، همجنان كه انتظار مىرود، بزرگتر از ضرايب كوتاهمدت هستند. سوم، ضريب متغير وابسته وقفه دادهده در كشورهاى آسياى شرقى بزرىتر از كشورهاى آسياى غربى است. اين امر منجر

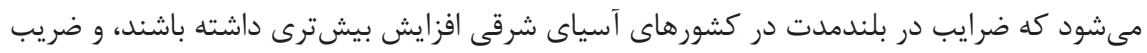

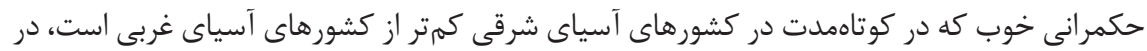
بلندمدت بزركتر از كشورهاى آسياى غربى باشد. بر اساس نتايج، سهم استفاده از سوختهاى سهرئ فسيلى

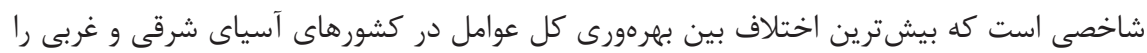

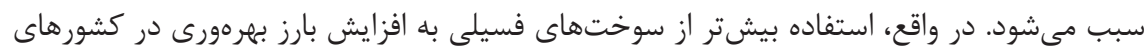

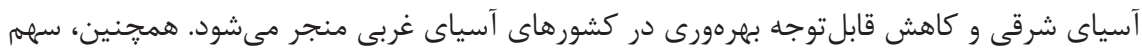
استفاده از سوختهاى فسيلى، حكمرانى خوب، رانتهاى نفتى، و سرمايه انسانى بلترتيب بيشترين

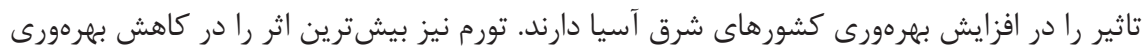

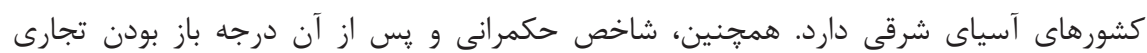
بيشترين اثر را در افزايش بهرهورى كل عوامل در كشورهاى آسياى غربى دارد. سهمه استفاده از سوختهاى فسيلى نيز عامل بيشترين كاهش بهرهورى كل عوامل در كشورهاى غرب آسياست. 


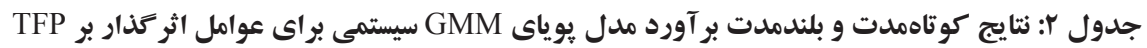
در كشورهاى آسياى شرقى و غربى بوري

\begin{tabular}{|c|c|c|c|c|}
\hline \multicolumn{2}{|c|}{ ضرايب بلندمدت } & \multicolumn{2}{|c|}{ ضرايب كوتاهمدت } & \multirow{2}{*}{ متغير } \\
\hline غرب & شرق & غرب & شرق & \\
\hline- & - & $\cdot / \mathrm{A}^{*}$ & $\cdot 19 Y^{*}$ & TFP $(-1)$ \\
\hline$\cdot / T r$ & $1 / \% q^{*}$ & $\cdot / \cdot r$ & $\cdot / 1 r^{*}$ & سرمايه انسانى \\
\hline.$/ 11$ & $1 / 4 \Lambda^{*}$ & $\cdot / \cdot 1$ & $\cdot / 1 r^{*}$ & رانتهاى نفتى \\
\hline $1 / 4 \varphi^{*}$ & $1 / A r^{*}$ & $\cdot / 1 \Lambda^{*}$ & $\cdot / 1 Q^{*}$ & شاخص حكمرانى \\
\hline$-Y / \cdot \Gamma^{\text {wawn }}$ & $\varphi / T^{*}$ & $-\cdot / Y Y^{*}$ & $\cdot / \widetilde{\omega} \omega^{*}$ & سوختهاى فسيلى \\
\hline$\cdot / \cdot r$ & $\cdot / \cdot r$ & $-\cdot 1 \cdot \cdots r$ & $\cdot / \cdot r$ & انرزىهاى تجديديذير \\
\hline$-\cdot / 1^{*}$ & $\cdot / 4 q^{*}$ & $-\cdot \cdot \cdot 1^{*}$ & $\cdot / \cdot r^{*}$ & FDI \\
\hline$-\cdot / 1 \Gamma^{*:}$ & $-\cdot / r^{*}$ & $-\cdot / \cdot r^{*}$ & $-\cdot / \cdot r^{*}$ & 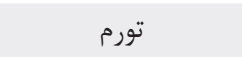 \\
\hline$\cdot 19 V^{*}$ & $-\cdot / \cdot V$ & $\cdot / \cdot \Lambda^{*}$ & $-\cdot \cdot \cdot \cdot 9$ & درجه باز بودن تجارى \\
\hline$-\cdot / 49 *$ & $-\cdot / 1$ & $-\cdot 1 \cdot 9^{*}$ & $-\cdot 1 \cdot \cdot 9$ & توسعه مالى \\
\hline- & - & .194 & $\cdot / V \cdot$ & Prob (J-Statistic) \\
\hline
\end{tabular}

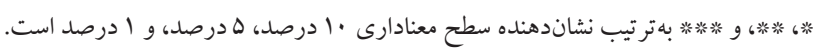

بر اساس ادبيات بهرهورى كل عوامل، سرمايه انسانى، حكمرانى خوب، و رانتهاى نفتى علاوه بر اثر

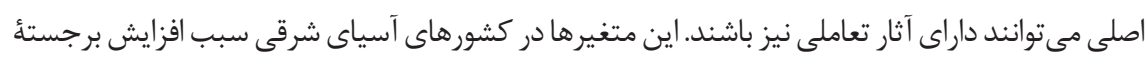

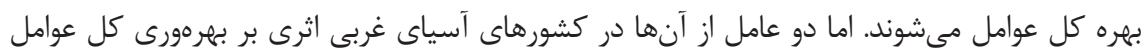

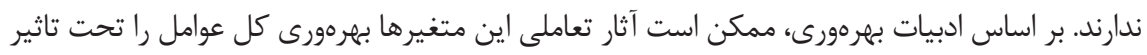

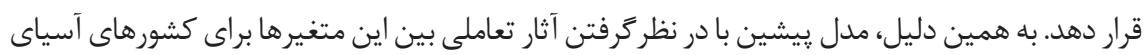

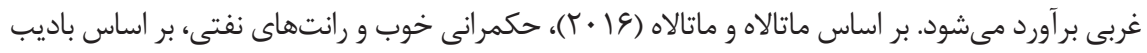

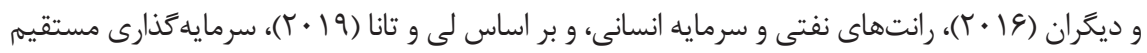

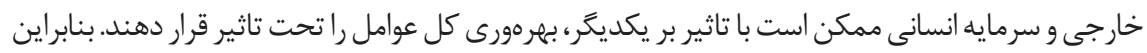

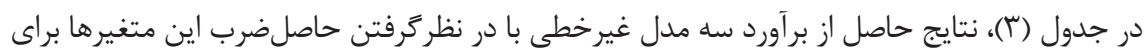

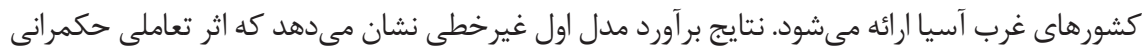

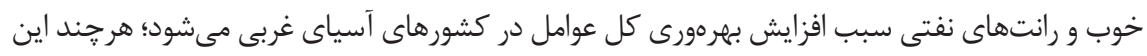


اثر در كوتاممدت اندك است، اما با محاسبه ضريب بلندمدت مىتوان يى برد كه اثر آن در بلندمدت بيشتر

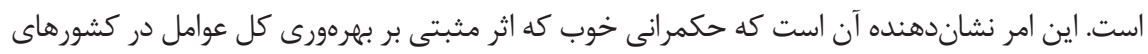
آسياى غربى دارد، در تعامل با رانتهاى نفتى مىتواند سبب افزايش بهرهورى كل عوامل در اين كشورها

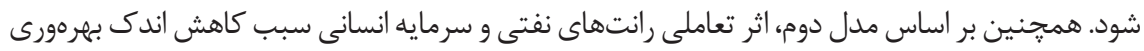
كل عوامل در كشورهاى آسياى غربى مىشود؛ هرجند اين اثر منفى در بلندمدت بيشتر است. در واقع،

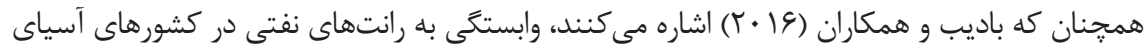

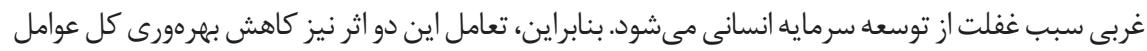
را به دنبال دارد. از طرفى در مدل سوم، اثر تعاملى سرمايه انسانى و سرمايهَذارى مستقيم خارجى در كشورهاى غرب آسيا نقشى در بهرهورى كل عوامل ندارد. بنابراين، سرمايه انسانى در كشورهاى غرب درب آسيا

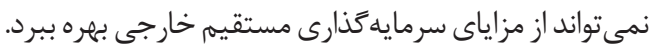

جدول r: نتايج بر آورد مدل غيرخطى ثوياى GMM سيستمى براى عوامل اثركذار بر TFP در كشورهاى آسياى غربى سيتى

\begin{tabular}{|c|c|c|c|}
\hline مدل سوم & مدل دوم & مدل اول & متغير \\
\hline$\cdot / \Lambda^{*}$ & $\cdot 1 \Lambda \varphi^{*}$ & $\cdot \mid \Lambda^{*}$ & $\operatorname{TFP}(-1)$ \\
\hline$\cdot / \cdot \Delta$ & $\cdot / \cdot r$ & $\cdot / \cdot r$ & سرمايه انسانى \\
\hline$\cdot / \cdot r$ & $\cdot 1 \cdot r^{* * *}$ & $\cdot / \cdot r^{\text {䋓 }}$ & رانتهاى نفتى \\
\hline.$/ 1 \Lambda^{*}$ &.$/ 1 V^{*}$ & $\cdot / 1 Q^{*}$ & شاخص حكمرانى \\
\hline 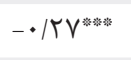 & $-\cdot / r \wedge$ &.$- \cdot 1 \cdot 9$ & سوختهاى فسيلى \\
\hline$-\cdot / \cdot \cdot 1$ & $-\cdot / \cdot v V$ & $\cdot 1 \cdot \cdot 1$ & انرزى هاى تجديديذير \\
\hline$\cdot 1 \cdot \cdot 9$ & $-\cdot 1 \cdot 1^{*}$ & $-\cdot / \cdot 1^{*}$ & FDI \\
\hline$-\cdot / \cdot r^{*}$ & $-\cdot / \cdot r^{*}$ & $-\cdot / \cdot r^{*}$ & 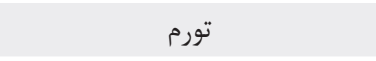 \\
\hline$\cdot / \cdot \Lambda^{*}$ & $\cdot 1 \cdot \Lambda^{*}$ & $\cdot / \cdot \Lambda^{* * * *}$ & درجه باز بودن تجارى \\
\hline.$- \cdot 1 \cdot 9^{* \prime}$ & $-\cdot 1 \cdot 9^{\prime \prime}$ & $-\cdot 1 \cdot 9^{*}$ & توسعه مالى \\
\hline- & - & $\cdot 1 \cdot r^{*}$ & رانتهاى نفتى × شاخص حكمرانى \\
\hline- & $-\cdot / \cdot r^{*}$ & - & رانتهاى نفتى × سرمايه انسانى \\
\hline$-\cdot / \cdot r$ & - & - & FDI × سرمايه انسانى \\
\hline . & . & .194 & Prob (J-Statistic) \\
\hline
\end{tabular}

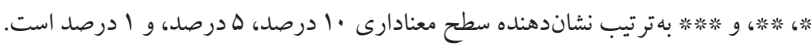




\section{و نتيجه تيرى}

در اين يزوهش، با هدف كشف و بررسى دلايل تفاوت بهرهورى در كشورهاى منتخب آسياى

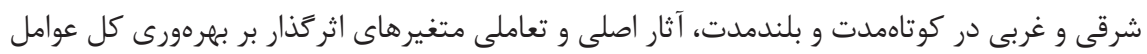
در اين دو گروه از كشورها با استفاده از جند مدل يويا و رويكرد گَشتاورهاى تعميميافته (GMM)، در

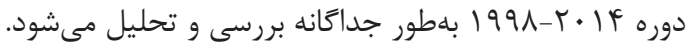

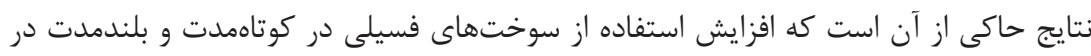
كشورهاى شرق آسيا سبب افزايش بهرهورى كل عوامل، و در كشورهاى غرب آسيا سبب كاهش بهرهورى كل عوامل مىشود و اين عامل مههمترين دليل تفاوت بهرهورى در كشورهاى آسياى شرقى بهى و غربى است. اين امر مىتواند به دليل استفاده گسترده از فناورىهاى كارايى انرزى درى در كشورهاي آسياى شرقى و استفاده كمتر از اين فناورىها در كنار قيمت ارزان انرزى در در كشورهاى آسياى آسئ غربى باشد. سمهم بيشتر سوختهاى فسيلى در كشورهاى آسياى غربى نسبت به كشورهاى آسياى شرقى از ديگر دلايل اين امر است. بنابراين، مىتوان كَت استفاده كارا از سوختهاى فئى فسيلى در كشورهاى شرق آسيا عامل استفاده بهينه و موثر از اين منابع انرزى ميىشود. از طرفى انى، افزايش استفاده

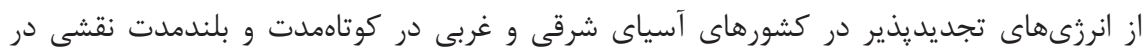
بهرهورى كل عوامل ندارد. اين امر مىتواند به دليل سهم كم انرزىهاى تجديديذير در مصرف انرزى در كشورهاى آسياى شرقى و غربى باشد. در واقع، هرجند سهم انرزى هاى تجديديذير از كل مصرف انرزى در كشورهاى آسياى شرقى بيشتر از كشورهاى غرب آسياست، اما همجٍنان عمده سمهم مصرف انرزى مربوط به سوختهاى فسيلى است.

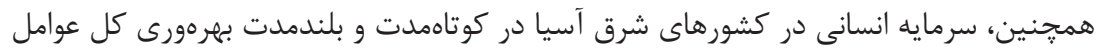

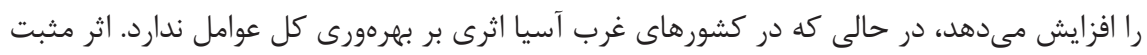

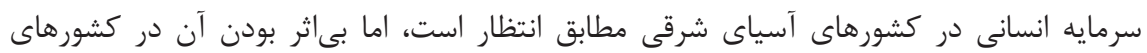

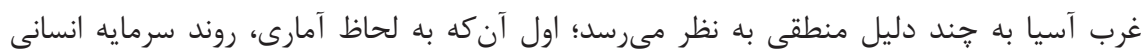

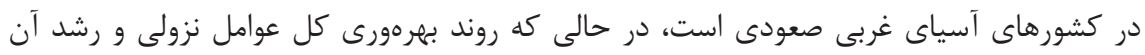
نوسانى است. بنابراين ارتباط نداشتن سرمايه انسانى با رشد TFP منطقى به نظر معرسى

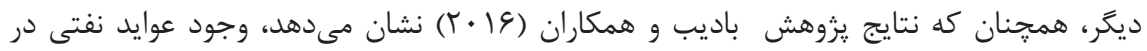
كشورهاى وابسته به نفت سبب غفلت از توسعه سرمايه انسانى مىشود و اين دومين دليل بىاثر بودن سرمايه انسانى بر بهرهورى در كشورهاى آسياى غربى است. سومين دليل آن است كه كمّيت 
آموزش در كشورهاى درحالتوسعه تفاوت جندانى با كشورهاى توسعهيافته ندارد، اما كيفيت آموزش كار در كشورهاى درحالتوسعه بسيار كمتر از كشورهاى توسعهيافته است (Hanushek, 2013). بنابراين،

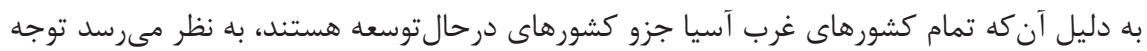
نكردن به آموزشهاى كاربردى و خلاقانه در اين كشورها سبب كاهش كيفيت آموزش و در در نتيجه بىاثر بودن سرمايه انسانى بر TFP مىشود. به علاوه، بى اثر بودن سرمايه انسانى بر بهرهورئ كلى كل عوامل

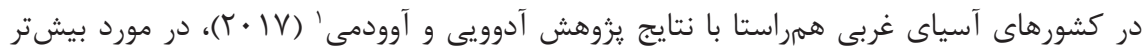

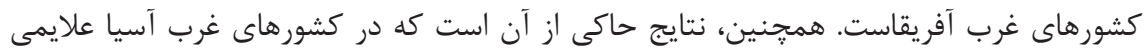

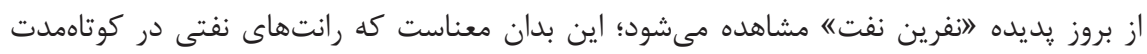
و بلندمدت در كشورهاى غرب آسيا اثرى بر بهرهورى كل عوامل ندارد. اما در كشورهاى شرق بـ آسيا

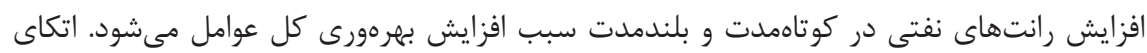

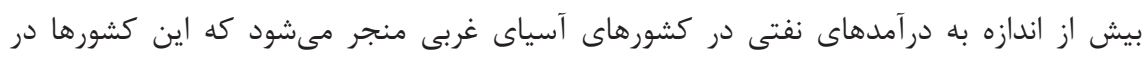

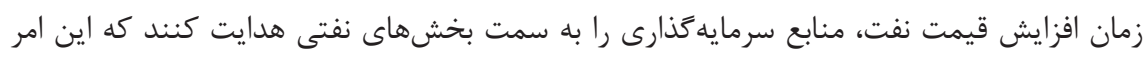

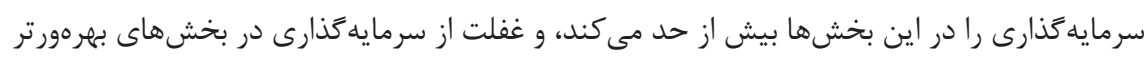

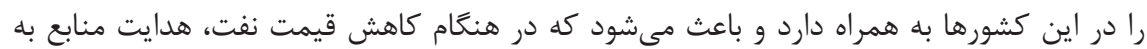
بخشهايى با بهرهورى بيشتر بهسادى امكان يذير نباشد. به علاوه، همجنان كه بيان شد، اتكاى به

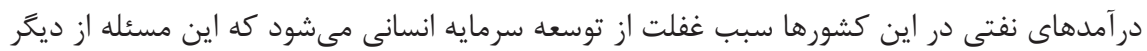

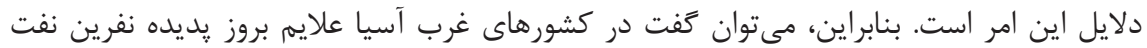

همجنين، حكمر انى خوب در كوتاهمدت و بلندمدت در كشورهاى شرق و غرب آسيا سبب افزايش

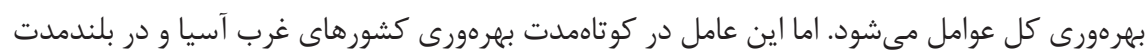

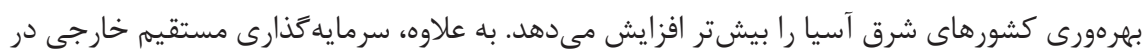

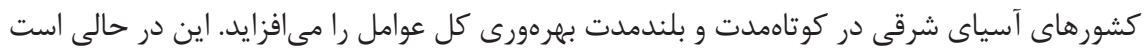

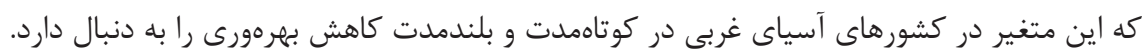

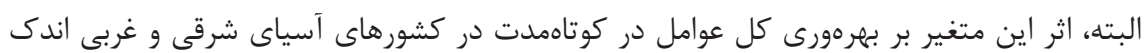

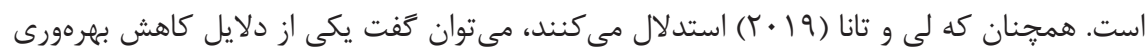
ناشى از FDI در كشورهاى غرب آسيا، كمبود سرمايه انسانى و ضعف نهادى است. در واقع، كمتر 
بودن سرمايه انسانى و ضعف نهادى در كشورهاى آسياى غربى منجر مىشود كه اين كشورها نتوانند

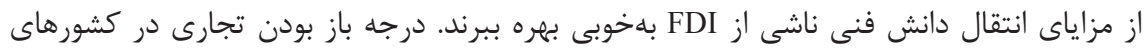

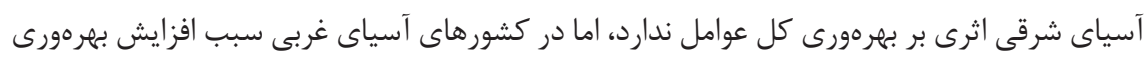

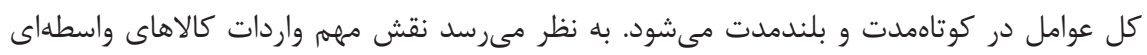

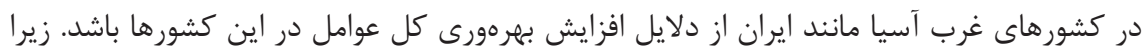

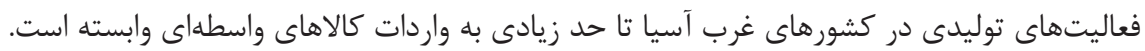

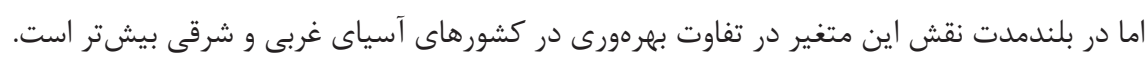

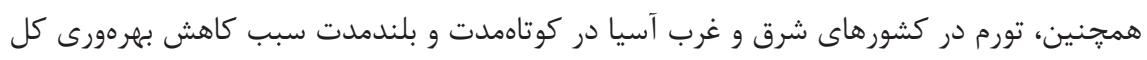

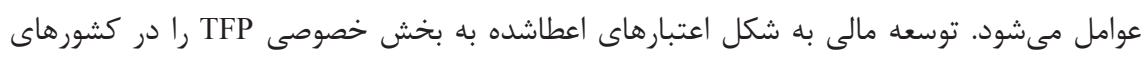

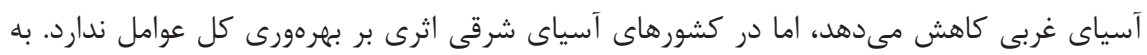

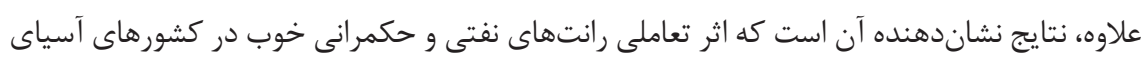

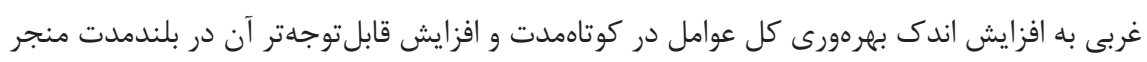

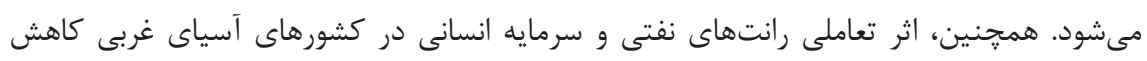

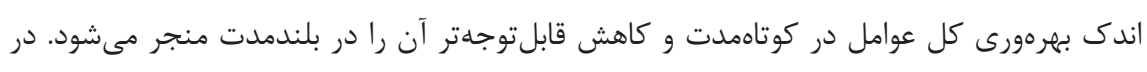

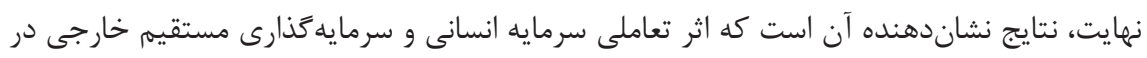

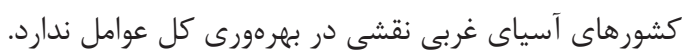

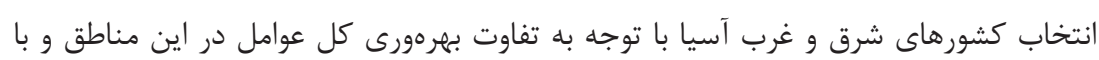

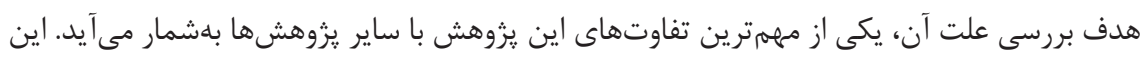

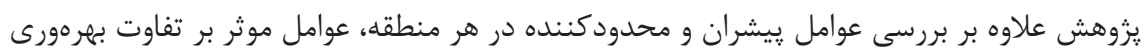

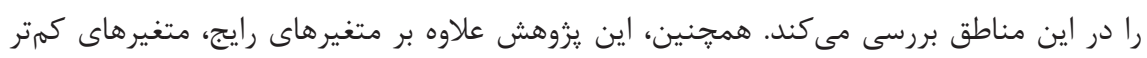

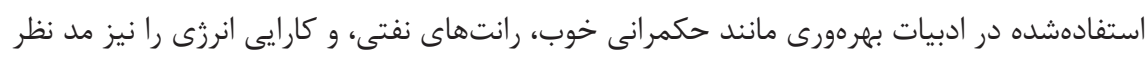

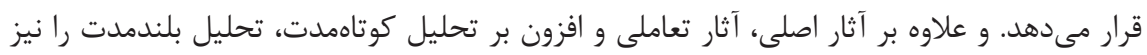

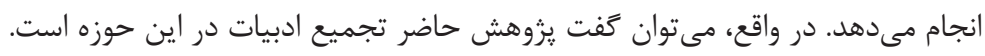

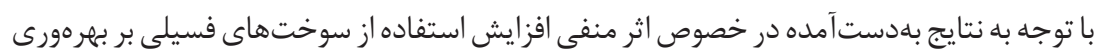

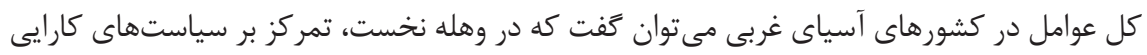

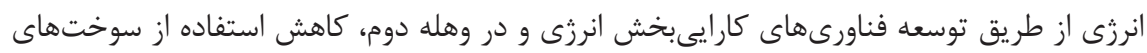

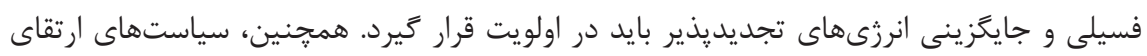


كيفيت سرمايه انسانى از طريق آموزشهاى كاربردى و خلاقانه مىتواند با فراهم آوردن زمينه نوآورى در فرايند توليد، سبب افزايش بهرهورى كل عوامل و رشد اقتصادى شود. همجنين، سرمايه انسانى با

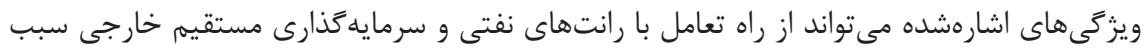
افزايش بيشتر بهرهورى و رشد اقتصادى شود. از طرفى، با توجه به بىاثر بودن رانتهاى نفتى بر

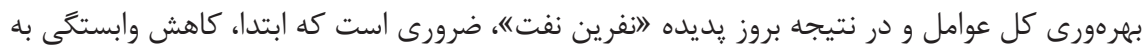

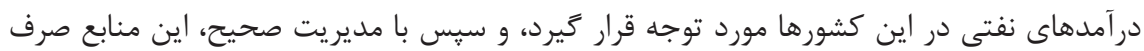
فرايندهاى تحقيق و توسعه شود.

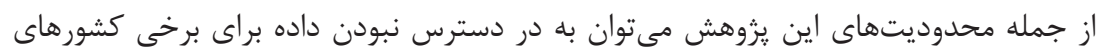

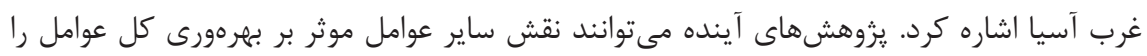

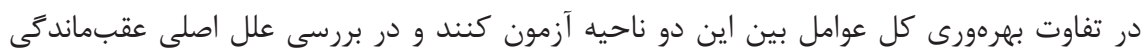

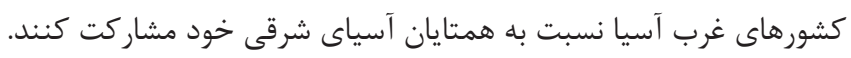

اسدزاده، احمد؛ محمدزاده، يرويز؛ اكبرى، اكرم، و عطايور، سميه (سوس (). تاثير سرمايه انسانى بر بهرهورى كل

$$
\text { الف) فارسى }
$$

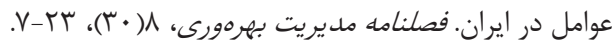

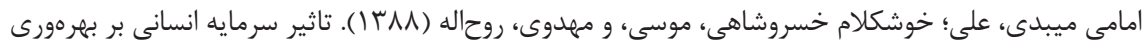

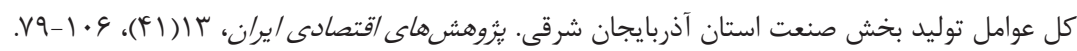

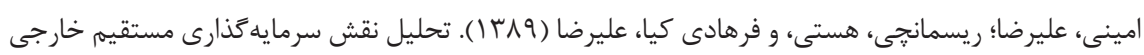

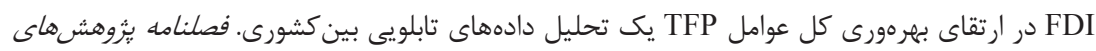

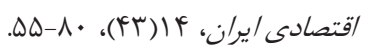

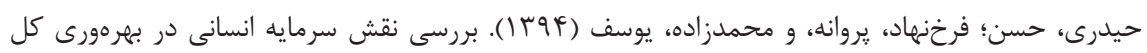

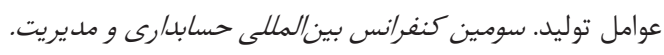

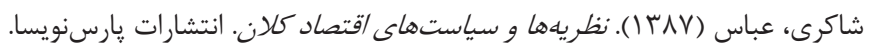

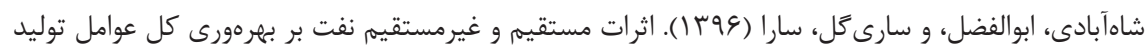

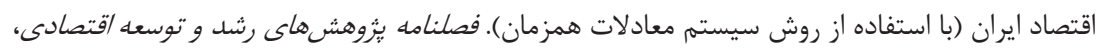




$$
\begin{aligned}
& \text { فلاحى، محمدعلى؛ جندقى ميبدى، فرشته، و اسكندرى يور، زهره ( (1) (1). تاثير ابعاد سرمايه انسانى بر بهرهورى }
\end{aligned}
$$

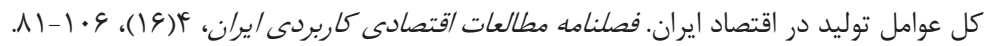

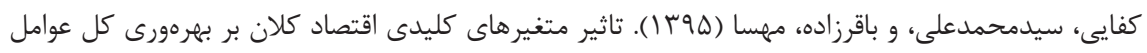

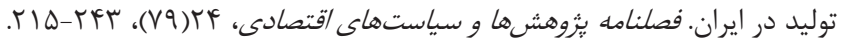

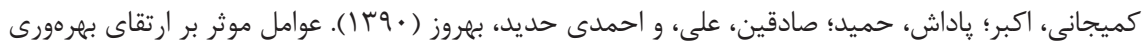

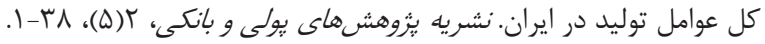

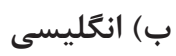

Adelakun, O. J. (2011). Human Capital Development and Economic Growth in Nigeria. European Journal of Business and Management, 3(9), 29-38.

Adewuyi, A. O., \& Awodumi, O. B. (2017). Biomass Energy Consumption, Economic Growth and Carbon Emissions: Fresh Evidence from West Africa Using a Simultaneous Equation Model. Energy, 119(1), 453-471.

Adhikary, B. K. (2011). FDI, Trade Openness, Capital Formation, and Economic Growth in Bangladesh: A Linkage Analysis. International Journal of Business and Management, 6(1), 16-28.

Ahmed, S., \& Mortaza, M. G. (2010). Inflation and Economic Growth in Bangladesh: 1981-2005. Working Papers id:3033, eSocialSciences.

Alfaro, L., Kalemli-Ozcan, S., \& Sayek, S. (2009). FDI, Productivity and Financial Development. World Economy, 32(1), 111-135.

Anwar, S., \& Sun, S. (2011). Financial Development, Foreign Investment and Economic Growth in Malaysia. Journal of Asian Economics, 22(4), 335-342.

Arellano, M., \& Bover, O. (1995). Another Look at the Instrumental Variable Estimation of Error-Components Models. Journal of Econometrics, 68(1), 29-51.

Ashraf, A., Herzer, D., \& Nunnenkamp, P. (2016). The Effects of Greenfield FDI and Cross-Border M\&As on Total Factor Productivity. The World Economy, 39(11), 17281755.

Attari, M. I. J., \& Javed, A. Y. (2013). Inflation, Economic Growth and Government Expenditure of Pakistan: 1980-2010. Procedia Economics and Finance, 5(1), 58-67.

Auty, R. M. (1994). Industrial Policy Reform in Six Large Newly Industrializing Countries: The Resource Curse Thesis. World Development, 22(1), 11-26.

Badeeb, R. A., Lean, H. H., \& Smyth, R. (2016). Oil Curse and Finance-Growth Nexus in Malaysia: The Role of Investment. Energy Economics, 57(1), 154-165.

Balcerzak, A. P., \& Pietrzak, M. B. (2016). Quality of Institutions and Total Factor Productivity in the European Union. Statistics in Transition New Series, 3(17), 497-514.

Barro, R. J., \& Lee, J. W. (2013). A New Data Set of Educational Attainment in the World, 1950-2010. Journal of Development Economics, 104(1), 184-198.

Barro, R. J., Mankiw, N. G., \& Sala-i-Martin, X. (1992). Capital Mobility in Neoclassical Models of Growth. National Bureau of Economic Research, No 4206. 
Becker, G. (1964). Human Capital. NBER, Columbia University Press.

Benos, N., \& Karagiannis, S. (2016). Do Education Quality and Spillovers Matter? Evidence on Human Capital and Productivity in Greece. Economic Modelling, 54(1), 563-573.

Blundell, R., \& Bond, S. (1998). Initial Conditions and Moment Restrictions in Dynamic Panel Data Models. Journal of Econometrics, 87(1), 115-143.

Borhan, H., Ahmed, E. M., \& Hitam, M. (2012). The Impact of CO2 on Economic Growth in ASEAN 8. Procedia-Social and Behavioral Sciences, 35(1), 389-397.

Calub, R. A. (2011). Linking Financial Development and Total Factor Productivity of the Philippines. University of the Philippines School of Economics (UPSE), Munich Personal RePEc Archive, No. 66042.

Campbell, O., \& Agbiokoro, T. (2013). Human Capital and Economic Growth: A Three Stage Least Squares Approach. Available at SSRN 2331545.

Conti, M., \& Sulis, G. (2016). Human Capital, Employment Protection and Growth in Europe. Journal of Comparative Economics, 44(2), 213-230.

Dasgupta, D., Keller, J., \& Srinivasan, T. (2002). Reform and Elusive Growth in the MiddleEast: What Has Happened in the 1990s? World Bank Washington, DC.

De Loecker, J. (2013). Detecting Learning by Exporting. American Economic Journal: Microeconomics, 5(3), 1-21.

Estrada, G. B., Park, D., \& Ramayandi, A. (2010). Financial Development and Economic Growth in Developing Asia. Asian Development Bank Economics Working Paper No. 233.

Fleisher, B., Li, H., \& Zhao, M. Q. (2010). Human Capital, Economic Growth, and Regional Inequality in China. Journal of Development Economics, 92(2), 215-231.

Freeman, D. G., \& Yerger, D. (1997). Inflation and Total Factor Productivity in Germany: A Response to Smyth. Weltwirtschaftliches Archiv, 133(1), 158-163.

Fuentes, R., Mishra, T., Scavia, J., \& Parhi, M. (2014). On Optimal Long-Term Relationship between TFP, Institutions, and Income Inequality Under Embodied Technical Progress. Structural Change and Economic Dynamics, 31(1), 89-100.

Garín-Mun, T. (2006). Inbound International Tourism to Canary Islands: A Dynamic Panel Data Model. Tourism Management, 27(2), 281-291.

Gerard, B. (2011). A Natural Resource Curse: Does It Exist within the United States? Claremont McKenna College, Senior Theses Paper 158.

Haider, S., \& Ganaie, A. A. (2017). Does Energy Efficiency Enhance Total Factor Productivity in Case of India? OPEC Energy Review, 41(2), 153-163.

Hanushek, E. A. (2013). Economic Growth in Developing Countries: The Role of Human Capital. Economics of Education Review, 37(1), 204-212.

Hsiao, C., \& Shen, Y. (2003). Foreign Direct Investment and Economic Growth: The Importance of Institutions and Urbanization. Economic Development and Cultural Change, 51(4), 883-896.

Kounetas, K., Mourtos, I., \& Tsekouras, K. (2012). Is Energy Intensity Important for the Productivity Growth of EET Adopters? Energy Economics, 34(4), 930-941.

Kumar, A., \& Kober, B. (2012). Urbanization, Human Capital, and Cross-Country Productivity Differences. Economics Letters, 117(1), 14-17.

Ladu, M. G., \& Meleddu, M. (2014). Is There Any Relationship between Energy and 
TFP (Total Factor Productivity)? A Panel Cointegration Approach for Italian Regions. Energy, 75(1), 560-567.

Lederman, D., Lesniak, J. T., Feenstra, R. C., Inklaar, R., \& Timmer, M. P. (2017). "The Next Generation of the Penn World Table. American Economic Review 2015, 105(10): 3150-3182http://dx.doi.org/10.1257/aer.20130954

Li, C., \& Tanna, S. (2019). The Impact of Foreign Direct Investment on Productivity: New Evidence for Developing Countries. Economic Modelling, 80(1), 453-466.

Li, T., \& Wang, Y. (2018). Growth Channels of Human Capital: A Chinese Panel Data Study. China Economic Review, 51(1), 309-322.

Lucas Jr, R. E. (1988). On the Mechanics of Economic Development. Journal of Monetary Economics, 22(1), 3-42.

Mahadevan, R., \& Asafu-Adjaye, J. (2005). The Productivity-Inflation Nexus: The Case of the Australian Mining Sector. Energy Economics, 27(1), 209-224.

Mankiw, N. G., Romer, D., \& Weil, D. N. (1992). A Contribution to the Empirics of Economic Growth. The Quarterly Journal of Economics, 107(2), 407-437.

Matallah, S., \& Matallah, A. (2016). Oil Rents and Economic Growth in Oil-Abundant MENA Countries: Governance is the Trump Card to Escape the Resource Trap. Topics in Middle Eastern and African Economies, 18(2), 87-116.

McGuinness, A. (2007). Institutions and Total Factor Productivity Convergence. Central Bank and Financial Services Authority of Ireland, 9/RT/07

Moghaddasi, R., \& Anoushe Pour, A. (2016). Energy Consumption and Total Factor Productivity Growth in Iranian Agriculture. Energy Reports, 2(1), 218-220.

Musolesi, A., \& Nosvelli, M. (2007). Dynamics of Residential Water Consumption in a Panel of Italian Municipalities. Applied Economics Letters, 14(6), 441-444.

Nelson, R. R., \& Phelps, E. S. (1966). Investment in Humans, Technological Diffusion, and Economic Growth. The American Economic Review, 56(1/2), 69-75.

Ojede, A. (2015). Is Inflation in Developing Countries Driven by Low Productivity or Monetary Growth? Economics Letters, 133(1), 96-99.

Pasten, R., Contreras, R., \& Molina, C. (2007). Energy Consumption, Total Factor Productivity and Growth in Latin America. Revista Chilena de Economía y Sociedad, 1(1), 23-49.

Psacharopoulos, G. (1994). Returns to Investment in Education: A Global Update. World Development, 22(9), 1325-1343.

Rath, B. N., Akram, V., Bal, D. P., \& Mahalik, M. K. (2019). Do Fossil Fuel and Renewable Energy Consumption Affect Total Factor Productivity Growth? Evidence from Cross-Country Data with Policy Insights. Energy Policy, 127(1), 186-199.

Romer, P. M. (1986). Increasing Returns and Long-Run Growth. Journal of Political Economy, 94(5), 1002-1037.

Romer, P. M. (1989). Human Capital and Growth: Theory and Evidence. National Bureau of Economic Research, No. 3173

Romer, P. M. (1994). The Origins of Endogenous Growth. Journal of Economic Perspectives, 8(1), 3-22.

Sequeira, T. N., Santos, M., \& Ferreira-Lopes, A. (2017). Income Inequality, TFP, and Human Capital. Economic Record, 93(300), 89-111. 
Shahbaz, M. (2012). Does Trade Openness Affect Long Run Growth? Cointegration, Causality and Forecast Error Variance Decomposition Tests for Pakistan. Economic Modelling, 29(6), 2325-2339.

Smyth, D. J. (1995). Inflation and Total Factor Productivity in Germany. Weltwirtschaftliches Archiv, 131(2), 403-405.

Solow, R. M. (1956). A Contribution to the Theory of Economic Growth. The Quarterly Journal of Economics, 70(1), 65-94.

Solow, R. M. (1957). Technical Change and the Aggregate Production Function. The Review of Economics and Statistics, 39(3), 312-320.

Tuan, C., Ng, L. F., \& Zhao, B. (2009). China's Post-Economic Reform Growth: The Role of FDI and Productivity Progress. Journal of Asian Economics, 20(3), 280-293.

Tugcu, C. T., \& Tiwari, A. K. (2016). Does Renewable and/or Non-Eenewable Energy Consumption Matter for Total Factor Productivity (TFP) Growth? Evidence from the BRICS. Renewable and Sustainable Energy Reviews, 65(1), 610-616.

Whalley, J., \& Zhao, X. (2010). The Contribution of Human Capital to China's Economic Growth. National Bureau of Economic Research, No. 16592.

Yazdan, G. F., \& Hossein, S. S. M. (2013). FDI and ICT Effects on Productivity Growth. Procedia-Social and Behavioral Sciences, 93(1), 1710-1715.

Yeboah, O.-A., Naanwaab, C. B., Saleem, S., \& Akuffo, A. S. (2012). Effects of Trade Openness on Economic Growth: The Case of African Countries. Paper Prepared for Presentation at the Southern Agricultural Economics Association Annual Meeting, Birmingham, AL, February 4-7, 2012

Zhou, D., Li, S., \& David, K. T. (2002). The Impact of FDI on the Productivity of Domestic Firms: The Case of China. International Business Review, 11(4), 465-484.

Zidouemba, P. R., \& Elitcha, K. (2018). Foreign Direct Investment and Total Factor Productivity: Is There Any Resource Curse? Modern Economy, 9(3), 463-483. 